Türk Coğrafya Dergisi
Sayı 62: 39-51, istanbul
http://www.tcd.org.tr

Hakemli Makale

Reviwed Article

\title{
Gönen Çayı'nın mendereslenme morfolojisi ve mendereslenmeyi etkileyen faktörler
}

\author{
Meandering morphology of Gönen Creek and factors affecting meandering
}

\section{Emre ÖZŞAHINª Deniz EKiNCí}

a) Namık Kemal Üniversitesi, Fen Edebiyat Fakültesi, Coğrafya Bölümü.

b) İstanbul Üniversitesi, Edebiyat Fakültesi, Coğrafya Bölümü.

Geliş/Received: 27.06.2013 Kabul /Accepted: 15.04 .2014

Sorumlu yazar/Corresponding author (E. ÖZŞAHIN) eozsahin@nku.edu.tr
Öz

Yeryüzünü şekillendiren en etkin dış kuvvet olan akarsuların yatak şekillerinden birisi de menderes tipinde olanlarıdır. Akarsuların yaptığı menderesler ile akarsu jeomorfolojisinin kanunları arasında sıkı bir ilişki vardır. Akarsuların mendereslenmesi üzerinde etkili olan etmen ve süreçlerin belirlenmesinde, buradaki röliyefin saptanmasında bu bağıntılar açıklayıcı ölçütler durumundadır. Yine aşınım döngüsü safhasının belirlenmesinde de menderesli akarsular ve menderes morfolojisi kıymetli ipuçları vermektedir. Bu çalışmada Gönen Çayı'nın mendereslenme özelliklerinin tespit edilmesi amaçlanmıştır. Bu amaç doğrultusunda mendereslenmeyi etkileyen faktörler ile mendereslenme morfolojisini ortaya koyan morfometrik özellikler, kıvrımlık indeksi ve mendereslenme oranı belirlenmiştir. Çalışmanın ilk aşamasında inceleme alanında mendereslenmeyi etkileyen faktörler açıklanmış ve etkilerine göre değerlendirilmiştir. Bu aşamada 1/25.000 ölçekli topografya haritaları ile Sayısal Yükseklik Modeli (GDEM) verileri kullanılmıştır. Çalışma sonuçları Gönen Çayı'nın bu mendereslenme morfolojisinin onun alt mecrasında genel taban seviyesine bağıı oluşan taşkın ovasında teşekkül ettiğini göstermiştir. Burada eğim değerleri küçülmüş, hız azalmış, akım miktarı artmış fakat beraberinde taşınan yük miktarı da artmıştır. Gerek suyun, gerekse suyun içindeki yükün kinetik enerjisinin azalması mevcut enkazı nakletmesine yetmemiş böylece mendereslenme meydana gelmiştir. Ayrıca Gönen Çayı'nın aşağı mecrasındaki kıvrımlıık indeksi $1 / 1.7$ ve 20 adet menderes kıvrımının yer aldığı sahadaki ortalama mendereslenme oranının ise $1 / 14$ olduğunu belirlenmiştir. Elde edilen sonuçlar, eğimin azalmasına bağıı olarak Gönen Çayı'nın yaptığı mendereslerin sayısının az, fakat her menderesin geniş ve büyük olduğunu göstermektedir. Akarsuyun geometrik özelliklerine ait değerlerin menderes boyutunun arttığı lokasyonlarda büyüdüğü, boyutun azaldığı alanlarda ise muhtemelen yük boyutları ile olan ilişkiye bağlı olarak küçüldüğü tespit edilmiştir.

Anahtar Kelimeler: Gönen Çayı, Mendereslenme Morfolojisi, Mendereslenme Oranı, Kıvrımlılık indeksi.

\section{ABSTRACT}

Rivers, the most effective external elements shaping the earth, have also meandershaped beds. There is a strong relationship between the meanders created by rivers and the rules of river geomorphology. These associations act as explanatory criteria in the identification of the relief in the area and in the determination of factors and processes that are effective in river meandering. Rivers with meanders and morphology of meandering also present valuable tips in the identification of erosion cycle phases. Current study aims to identify meandering characteristics of Gönen Creek. In line with the aims of the research, factors that affect meandering were examined along with the identification of sinuosity and meandering rates, morphometric features which present the morphology of meandering. In the first part of the study, factors that affected meandering in the research area were explained and assesses according to their effects. In this phase of the study, topography maps scaled 1/25.000 and Digital Elevation Model (GDEM) data were utilized. Study results show that morphology of meandering in Gönen Creek is formed in the flood valley formed according to general floor/base level in its lower channels. Here, slope values are found to be lessened, speed decreases and amount of flow increases however the amount of load that is transported increases. The decreases of kinetic energy both in the water and in the load carried in the water result in meandering since the kinetic energy is not sufficient anymore to transport the existing 
debris. Sinuosity rate in the lower channels of the Gönen Creek was identified to be 1/1.7 and the average meandering rate in the area that includes $\mathbf{2 0}$ meanders was identified to be 1/14. Results show that the number of meanders created by Gönen Creek due to decreases in the slope is small but each meander is large and wide. It was also seen that values based on the geometric characteristics of the river expand in locations where the meander size increases but they lessen in locations where the meander sizes decrease probably based on the relationship with the load size.

Keywords: Gönen Creek, Morphology of Meandering, Rate of Meandering, Rate of sinuosity.

\section{GiRiş}

Yeryüzünü şekillendiren en etkin dış kuvvet olan akarsular (Hoşgören, 2007, 2012; Erinç, 2012), yatak kıvrımlılığı ve yatağın örgülenme oranı dikkate alındığında (Aslan, 2007) çeşitli türde yatak şekillerine sahiptirler (Goudie, 2004). Bu yatak şekilleri, düz, menderesli, örgülü ve çatallı olarak sınıflandırılmaktadır (Leopold ve Wolman, 1957; Hasfurther, 1985; Zavoıanu, 1985; Doğan, 2012). Bu şekiller akarsuyun boyuna profilinde mecranın konumunu ortaya koyduğu gibi aşınım döngüsü bakımından da safhanın izahına imkân vermektedir.

Akarsu yatak şekilleri içerisinde en çok dikkat çekeni ve araştırılanı ise menderesli tipidir (Leopold ve Wolman, 1957; Dai ve Tang, 2012; Güneralp vd., 2012; Riley ve Rhoads, 2012). Menderes terimi, Türkiye'deki bugün Menderes Nehri olarak bilinen kıvrımlı bir akarsuyun ismi olan "Miandras (Latince'de Meaender)" kelimesinden gelmektedir (Hasfurther, 1985; Güneralp vd., 2012). Bu terim, ilk başlarda genellikle düz olmayan akarsu yatak şekillerinin hepsini kapsar şekilde kullanılırken, daha sonra yalnız düzenli bir " $S$ " şekline sahip olan akarsu yatağı formlarının tanımlanmasında kullanılmıştır (Hasfurther, 1985).

Akarsuların yaptığı menderesler ile akarsu jeomorfolojisinin kanunları arasında sıkı bir matematiksel ilişki vardır. Bu ilişki akarsuların mendereslenme özelliklerinin tespit edilmesi bakımından önemlidir. Bu tespit, sedimantasyon süreçleri (Nanson ve Beach, 1977; Howard, 1992; Sun vd., 1996; Gilvear vd., 2000) ile hidrolojik ve ekolojik süreçlerin (Salo vd., 1986; Ward vd., 2002) açıklanmasında ve akarsu-taşkın ovası ekosistemi üzerindeki insan etkisinin de anlaşılmasında (Piegay vd., 2005; Gurnell vd., 2006; Kondolf, 2006) yararlı olmaktadır (Güneralp vd., 2012). Ayrıca jeomorfolojik oluşum ve gelişim sürecinin daha sağlıklı bir şekilde yorumlanması açısından da dikkate değerdir.

$\mathrm{Bu}$ çalışmada Gönen Çayı'nın aşağı mecrasındaki mendereslenme özelliklerinin tespit edilmesi amaçlanmıştır. Bu amaç doğrultusunda mendereslenmeyi etkileyen faktörler ile mendereslenme morfolojisini ortaya koyan morfometrik özellikler, kıvrımlık (sinosite) indeksi ve mendereslenme oranı belirlenmiştir.

$\mathrm{Bu}$ çalışmada elde edilen bulgular ve sonuçların konu hakkında ileride oluşturulabilecek kuramsal çalışmalara ve hipotezlerin geliştirilmesine yardımcı olacağı muhtemeldir. Bu çalışma akarsu mendereslenmeleri konusu ile ilgili olarak çalışmak isteyen akademisyenlere kendi çapında bir kaynak teşkil edebilir. Ayrıca bu çalışma Türkiye'de akarsuları için benzer özelliklere ait bir durum değerlendirmesi yapılmasını da sağlayabilir.

\section{MATERYAL ve YÖNTEM}

Gönen Çayı örneğinde mendereslenme özelliklerinin tespit edilmesi anlayışı çerçevesinde gerçekleştirilen bu çalışma, hazırlık; gözlem, ölçme ve istatistik; analiz ve sonuç olmak üzere dört aşamada tamamlanmıştır.

Çalışmanın hazırlık safhasında, öncelikli olarak konu ve alan ile ilgili literatür taranarak gözden geçirilmiştir. İnceleme alanındaki mendereslenme özellikleri temel altık harita olarak 1/25.000 ölçekli topografya paftalarından yararlanılarak ortaya çıkarılmıştır. Ayrıca bu aşamada Google Earth (KMZ) formatında 2012 tarihli Cnes/Spot Image uydu görüntüsünden de faydalanılmıştır. Alana ait morfometrik özellikleri kapsayan analizlerde ise Japonya Ekonomi, Sanayi ve Ticaret Bakanlığı (METI) Dünya Uzaktan Algılama Veri Analiz Merkezi (ERSDAC) ve Amerika Ulusal Havacılık ve Uzay Dairesi (NASA) tarafından üretilen 30×30 $m$ çözünürlüğündeki Sayısal Yükseklik Modeli (GDEM) verisi kullanılmıştır. Çalışmanın tematik haritalarının oluşturması ve topografyaya ait ölçümler Arclnfo/ArcMap 10.1 paket programı destekli olarak CBS ortamında gerçekleştirilmiştir. Yine bu safhada, elde edilen matematiksel veriler Microsoft Excel programında düzenlenmiştir.

Çalışmanın gözlem, ölçme ve istatistik aşamasında, havza alanında sistematik bir şekilde arazi çalışmaları yapılmıştır. Bu esnada, inceleme alanında mendereslenmeyi etkileyen faktörler tespit edilmiş ve etkilerine göre değerlendirilmiştir. Bu tespit ve değerlendirmeler inceleme alanında yersel örneklem verilerinin toplanmasıyla gerçekleştirilmiştir. Zira akarsu süreçleriyle ilgili yapılan güncel bir çok çalışmada aynı yöntem kullanılmıştır (Hammad vd., 2004; Doğan, 2009).

Çalışmanın sonuç aşamasında ise hem literatür taraması hem de arazi çalışmalarından elde edilen veriler, güncel çalışmalar ışığında titizlikle kaleme alınmıştır.

\section{INCELEME ALANININ KONUMU ve GENEL ÖZELLIKLERI}

Inceleme alanı, Türkiye'nin kuzeybatı kesiminde yer almakta olup, Gönen Çayı havzasının aşağı mecrasına karşılık gelmektedir (Şekil 1). Coğrafi Koordinat Sistemine göre $27^{\circ} 21^{\prime} 40^{\prime \prime}-27^{\circ} 48^{\prime} 08^{\prime \prime}$ doğu boylamları ile $39^{\circ} 57^{\prime}$ 
$17^{\prime \prime}-40^{\circ} 21^{\prime} 40^{\prime \prime}$ kuzey enlemleri arasında kalmaktadır (Şekil 1).

Inceleme alanı, batıdan Hodul Dağı, Tahtalı Dağı ve Armutçuk Dağı, doğudan Gönen-Manyas eşiği, güneyden yüksek plato sahası ve kuzeyden de Marmara Denizi ile çevrelenmiştir. Gönen havzası sınırındaki boğazdan (Gönen Çayı güney boğazı) giriş yapan Gönen Çayı, aynı ad ile anılan alüvyal taşkın ovasını oluşturup, Gönen Çayı kuzey boğazı vasıtasıyla Gönen Çayı deltasını yaparak Marmara Denizine dökülmektedir (Şekil 1).
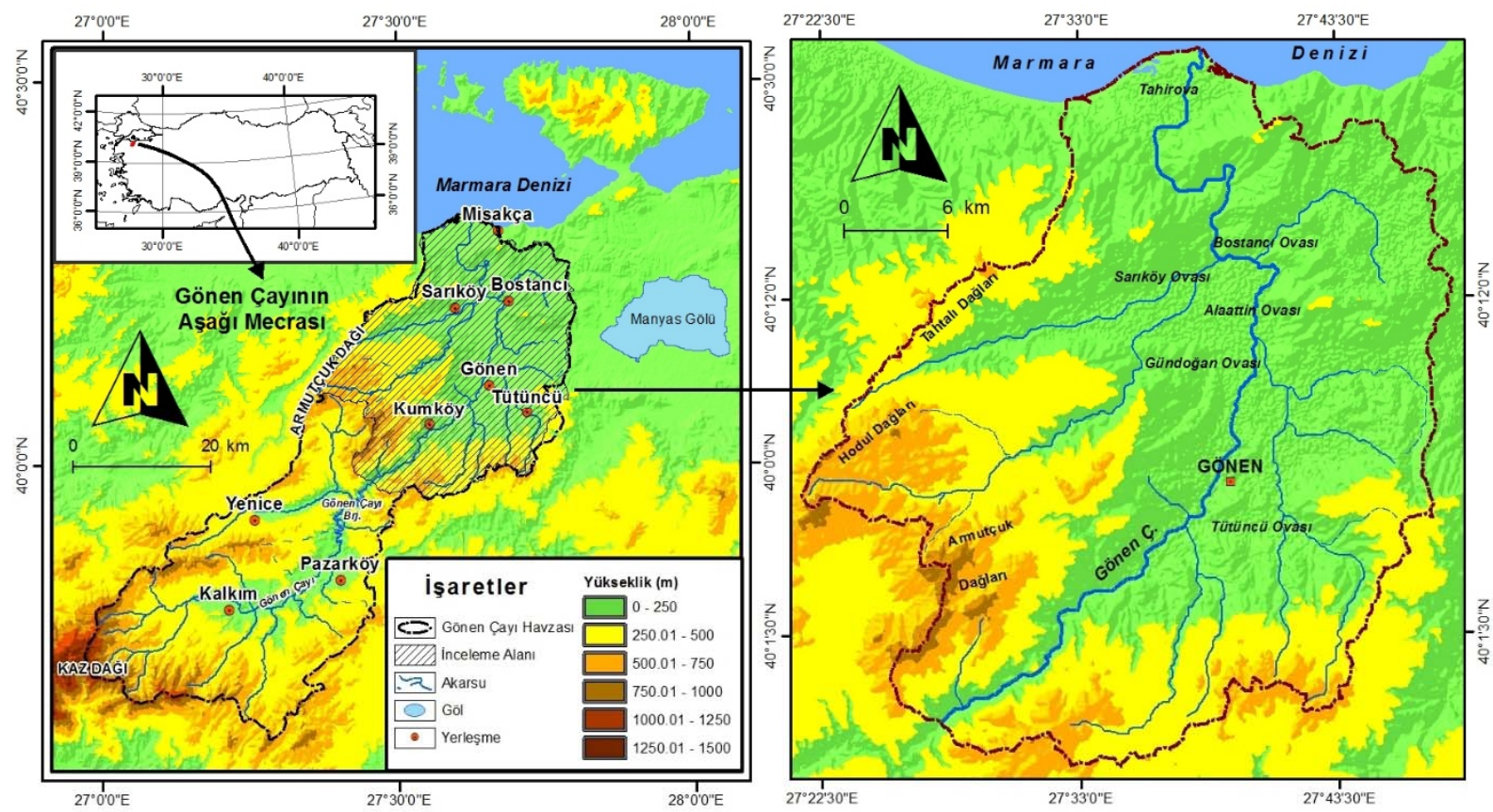

Şekil 1. İnceleme alanının lokasyon haritası.

Figure 1. Location map of the study area.

Inceleme alanında, en yaşlı birimi Permiyen'e ait karbonatlar oluşturmaktadır. Temele ait bu kayaçların üzerinde ise sırasıyla, Permo-Triyas'a ait karbonatlı taşlar, Triyas'a ait şist, fillit ve mermer türünden metamorfik kayaçlar, Jura dönemine ait neritik ve pelajik kireçtaşları, Oligosen ve Miyosen yaşlı volkanik kayaçlar, Pliyosen'e ait ayrılmamış karasal kırıntılar ve Kuvaterner alüvyonları bulunmaktadır (Efe, 1986; Kantürer, 1993; Özşahin, 2011).

İnceleme alanında Tahtalı, Hodul ve Armutçuk dağları, Sarıoluk ve Alacaoluk platoları ile Gönen ve Tahirova ovaları ana jeomorfolojik ünitelerdir (Özşahin, 2011). Bunun yanında inceleme alanının güneyinde ve kuzeyinde Gönen Çayı'nın açtığı boğazlar, aşınım yüzeyleri, çeşitli tiplerdeki vadiler, birikinti koni ve yelpazeleri de elemanter unsurlar olarak dikkat çeker (Efe, 1994; Efe vd., 2011).

Sahada yazları sıcak ve kurak, kışları ise ılık ve yağışlı Akdeniz iklimi ile her mevsim yağışlı bir özellik gösteren Karadeniz ikliminin etkileri hissedilmektedir. Yani bu alandaki iklimin, bir nevi geçiş karakterine (Akdeniz ikliminden Karadeniz iklimine) sahip olduğu söylenebilir (Özşahin, 2008). Gönen Meteoroloji istasyonunun verilerine göre (19752010) yıllık sıcaklık ortalamasının $14.1^{\circ} \mathrm{C}$ olduğu inceleme alanında, yıllık yağış toplamı $646.9 \mathrm{~mm}$ 'dir.

Tektonik açıdan Kuzey Anadolu Fay (KAF) hattının güney kanadının etkisi altında şekillenmiş bir konumda bulunan bu sahada, çok sayıda kırık hattı gözlemlenir. Yenice-Gönen ve Gönen-Manyas fayları bu alandaki en önemli tektonik hatlardır. Bu ana fayların kolları olarak inceleme alanında birçok tali fayda mevcuttur (Efe, 1994; 1995; Özşahin, 2011; Selim ve Tüysüz, 2013).

Gönen Çayının alt akaçlama havzasında yer alan inceleme alanında akarsular basit "Yağmurlu Akdeniz Rejimi" karakterine sahiptir (Efe, 1996). Akarsular baskın bir şekilde yağışlara bağımlı olarak bulunur ve akım verileri yağış verileri ile paralellik gösterir. Düzensiz bir akım rejimine sahip olan Gönen Çayı'nın ortalama debisi $14.4 \mathrm{~m}^{3} / \mathrm{s}$ olmasına rağmen, yağışlı dönemdeki boşalımı 185-250 $\mathrm{m}^{3} / \mathrm{s}$ arasındadır. Gönen Çayı'nın maksimum anlık boşalımı $911 \mathrm{~m}^{3} / \mathrm{s}$, minimum anlık boşalımı ise $0.024 \mathrm{~m}^{3} / \mathrm{s}^{\prime}$ dir. Yıllık ortalama akım özelliklerine göre Gönen Çayı'nın düzensizlik katsayısı 8'dir (Efe, 1996).

Gönen Çayı'nda denüdasyon miktarı ise kurak dönemde (210 gün) 0.003 ton $/ \mathrm{km}^{2} / \mathrm{yıl}$, yağışlı dönemde (150 gün) ise $0.141 \mathrm{ton} / \mathrm{km}^{2} / \mathrm{yll}$ olarak tahmin edilmektedir (Kazancı vd., 1997). Gönen Çayı'nın sahip olduğu bu denüdasyon hızı aynı iklim kuşağında yer alan diğer Güney Marmara akarsularının denüdasyon hızları ile karşılaştırıldığında, Gönen Çayı'nın denüdasyon hızının daha yüksek olduğu görülür. Bu durum Gönen Çayı drenaj havzasının orta ve yukarı bölümlerinin tektonik olarak daha aktif bir kuşakta yer almasından dolayı genç ve sarp bir morfolojik yapı göstermesi, ana akarsuların doğrudan aktif fay zonlarına yerleşmiş olması ve akarsuyun havzasında önemli bir çökelme ortamının (doğal veya yapay göl) bulunmaması gibi faktörlerin bir sonucudur (Kazancı 
vd., 1999: 41). Ancak 1997 yılında bu çayın üzerine Gönen Barajı'nın yapılması ile denüdasyon miktarı ortalama olarak düşmüştür.

Inceleme alanındaki akarsuların süreçleri sonucunda biriktirilen materyaller üzerinde Entisoller, farklı yaşlardaki kireçtaşları üzerinde Alfisoller, killi kayaçların hakim olduğu arazilerde Vertisoller, Tersiyer'e ait volkanik kayaçlar üzerinde ise İnceptisoller yayılış göstermektedir (Efe, 1999).

İnceleme alanı, Türkiye'nin ekolojik bölgelerine göre Marmara Geçiş Bölgesi'nin hem Kurakçıl Orman (maki, kızılçam), hem de Yarı Nemli Orman (karaçam, meşe) bölümleri içerisinde yer alır (Atalay, 1994; 2002). Bitki örtüsü üzerinde iklim karakterinin etkisi yoğun bir şekilde hissedilmektedir. Sahadaki ormanlık alanlarda genellikle meşe türleri ve kızılçamlar baskın bir şekilde görülmektedir. Bunun yanında çeşitli maki türleri (akçakesme, sandal, katran ardıcı, tespih, kocayemiş) de alanda yayılış göstermektedir (Efe, 1999).

\section{GÖNEN ÇAYIN'DA MENDERESLENMEYI ETKILEYEN FAKTÖRLER}

Akarsuların menderesler resmetmesiyle akarsu drenaj havzası arasında sıkı bir ilişkili vardır (Atalay, 1986). Özellikle drenaj havzasının gösterdiği bazı özellikler mendereslenme karakterini ve oluşumunu etkilemektedir. Bu faktörler aynı zamanda akarsu gelişimiyle de etkileşimlidir (Hasfurther, 1985). Yersel örneklem verilerine dayanarak Gönen Çayı'nın aşağı mecrasında karakteristik menderesler çizmesinde havzasının sahip olduğu topografya, jeoloji, jeomorfoloji, hidrografya, iklim, toprak, zemin örtüsü ve insan gibi özelliklerin etkili olduğu belirlenmiştir. Bu faktörlere bağlı olarak ana akarsu kolunun alt mecrasında menderesli yatak şekli gelişmiştir. Ayrıca bu özelliklerin uygunluk düzeyi ana akarsu kolundaki mendereslerin geometrisinin büyümesine de neden olmuştur.

Gönen Çayı'nın inceleme alanında 20 tane menderesin yapmıştır. Bu mendereslerden 8 tanesi saplanmış gömük menderes ( $M$ 1, M 2, M 3, M 4, M 5, M14, M 15, M 16), diğerleri ise taban seviyesine bağlı olarak gerçekleşen mendereslerdir. $\mathrm{Bu}$ nedenle saplanmış gömük mendereslerin gelişiminde en etkili faktör jeoloji ve jeomorfoloji iken, diğer mendereslerin gelişiminde aynı faktörlerin yanında diğer ilgili faktörlerde rol oynar.

Mendereslenme yükselti ve eğim değerlerinin azaldığı düz ve düze yakın yatay sahalarda oluşmaktadır. Sahada röliyef pürüzlülük oranının azaldığı ovalık silik topografyada akarsuyun akış hızı azalmakta ve yükü taşıyacak kinetik enerji kifayetsiz hale dönüşmektedir (İbırak, 1978). Bu bağlamda inceleme alanında yükseltinin 0-10 m, eğim değerinin $1^{\circ}-2^{\circ}$ arasında olduğu kuzeye bakan yamaçlarda menderes oluşumu ve gelişimi gerçekleşmiştir. Gerçekten de aşağıda morfometrik özellikler başlığı altında açıklanacağı üzere sahanın yükseklik, eğim ve bakı özellikleri incelendiğinde durumun belirtilen şekilde olduğu anlaşılmaktadır.

Bununla birlikte mendereslerin kendi yapısından kaynaklanan iç ve dış bükeylik aşındırma, taşıma ve biriktirme süreçlerine etki yaparak şekillenmeyi kontrol etmektedir. Dışbükey yamaçlarda aşınan malzeme genellikle fazla, buna karşılık içbükey yamaçlarda biriktirme baskın olduğu için daha azdır. Ancak içbükey yamaçların üst kısımları aşınım için daha elverişlidir (Verstappen, 1983; Atalay, 1986; Ekinci, 2004). Dışbükey yamaçlar, yüzeysel akışın çeşitli yönlere dağılımını sağlayarak, toprağın taşınmasını kolaylaştırmaktadır. Bu durum akarsu yatağında birikime ve yamaç eğim değerlerinin azalarak var olan mendereslerin geometrik özelliklerinin de değişmesine neden olmaktadır.

Mendereslerin gelişimi ile sediment miktarı ve doğasını etkileyen en önemli faktörlerden birisi jeoloji'dir (Hasfurther, 1985). Jeolojik özellikler daha çok litolojik yapı bakımından etkili olmaktadır. Bu bağlamda inceleme alanında litolojinin Kuvaterner'e ait depolardan müteşekkil olduğu yerler mendereslenmenin en yaygın olduğu arazilerdir (Fotoğraf 1). Zira bu durumun benzer şekilde olduğu literatürde de açıklanmıştır (Hasfurther, 1985). Yine fay hatları ile uyumlu ve yapıya uymuş mecralarda da mendereslerin geliştiği gözlenmektedir (Şekil 2). Bu bağlamda inceleme alanında M 10, M 11, M 18, M 19, M 20 numaralı mendereslerin dışındaki tüm menderesler fay kontrolünde gelişmiş olduğu söylenebilir. Ancak en belirgin fay etkinliği saplanmış gömük mendereslerin bulunduğu lokasyonlarda olduğu belirlenmiştir.

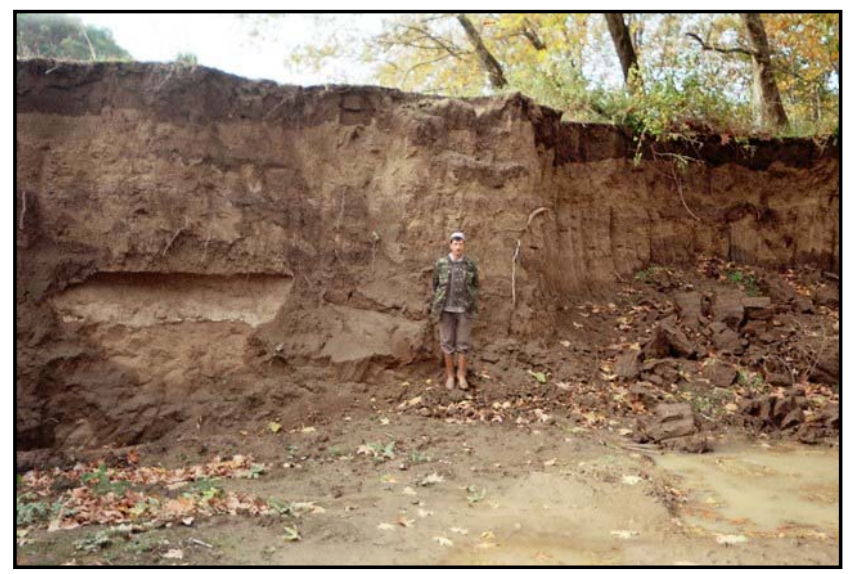

Fotoğraf 1. İnceleme alanındaki alüvyal dolgular.

Photo 1. Alluvial deposits in the study area.

İklim özelliklerinden yağış ve sıcaklık akım ve zemin örtüsü üzerinde yaptıkları etkiyle şekillendirici rol oynamaktadır. Doğrudan yağışlarla beslenen ve basit rejim karakterinde olan Gönen Çayı'nda yağış ve akarsuyun akım değeri arasında sıkı bir ilişki vardır. Bu nedenle hidrografya özellikleri, yağış ve akış değişkenlerini etkileyerek, ana akarsu kolu tarafından oluşturulan menderes sistemlerinin de gelişiminde etkili olabilmektedir (Hasfurther, 1985). Gönen Çayı'nda yağışın arttığı kış aylarında akım ve akarsuyun taşıdığı yük miktarı artmakta ve bu süreç mendereslenmenin hızını belirlemektedir.

Akarsu yatağının kaynaktan ağız kısmına kadar olan boyuna profil yapısı da mendereslenmenin aşağı mecrada gerçekleşmesinin ispatı açısından oldukça önemli bir göstergedir. Bu bakımdan inceleme alanında Gönen 
Çayı'nın 20 m'ler civarında akış göstermesi boyuna profil özelliklerine de yansımış ve akarsuyun 20 m'ler civarında menderesli yatak şekli oluşturmasına neden olmuştur. Gönen Çayı deltasında ise 0-10 m'lerde menderesli akışını sürdürerek denize ulaşmaktadır (Şekil 3).

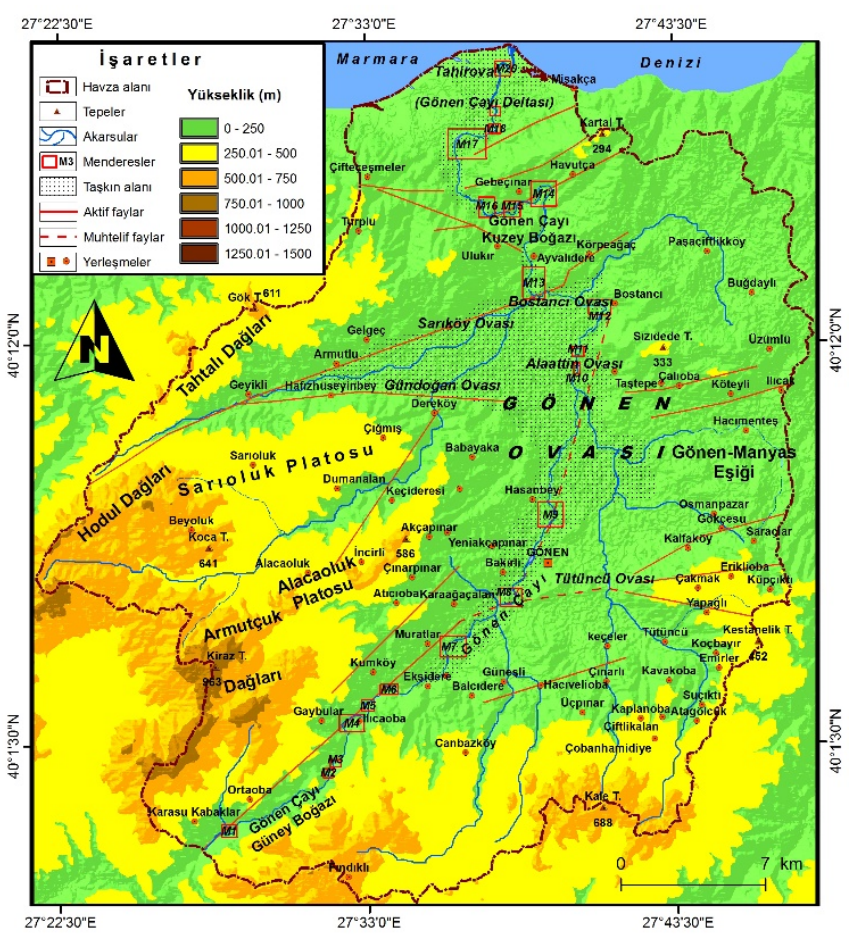

Şekil 2. Gönen Çayı'nın aşağı mecrasında yaptığı menderesler.

Figure 2. Gönen Creek that meanders in the sub-basin.

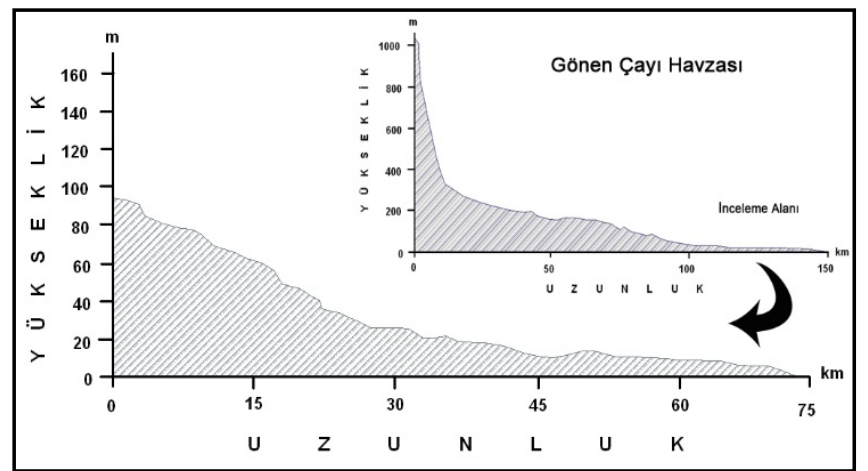

Şekil 3. Gönen Çayı'nın havzasındaki ve inceleme alanındaki boyuna profili.

Figure 3. Longitudinally profile in the study area and basin of Gönen Creek.

Akarsularda tam gelişmiş bir mendereslenme; akarsuyun gücü, akış hızı, yükün miktarı ve özelliklerine bağlı olarak şekillenen suyun ve yükün kinetik enerjisine ve yatağın litolojisine bağlıdır. Bu nedenle kolay taşınabilir nitelikteki yük, bu yükü taşımaya ve aynı zamanda yana aşındırma aktivitesinde bulundurmaya imkân veren akış hızı elverişli şartlar sunmaktadır (Erinç, 2012).

İnceleme alanında akarsu gücünün azaldığı ve akış hızının düştüğü Gönen Ovası ve Gönen Çayı deltasında mendereslenmenin oluşması tesadüfi değildir. Gönen Çayı'nın akım miktarı arttıkça, yaptığı menderes yayı veya akarsu büklümü de genişlemiştir. Yine Gönen Çayı'nın enine kesitindeki genişliği de ivme kuvvetini arttırmıştır. İvme kuvveti arttığı için mendereslerin sayısı düşmüş fakat büyüklükleri artmıştır. Böylece akarsuyun menderesleri daha belirginleşmiş ve gelişmiştir.

Kaba taneli topraklardan ince taneli topraklara doğru toprak geçirimliliği azalmakta ve bu durum akarsularla taşınan madde miktarını arttırmaktadır. Özellikle killi ve siltli topraklar menderesli akarsu kanallarının gelişimi açısından uygun bir nitelik taşır. Bu nedenle inceleme alanındaki Entisoller menderes oluşumu ve gelişimi bakımından daha uygun bir karaktere sahiptir. Bu toprak türünün siltli karakter kazandığı alanlar ise en gelişmiş menderes niteliklerine sahip arazilerdir.

Bitki örtüsü özellikleri de aşınım süreçlerine etki yaparak taşınan madde miktarını ve dolaylı olarak da mendereslenmeyi etkilemektedir. Kesif vejetasyonun olduğu alanlarda toprak kayıpları az iken, zemin örtüsünün olmadığı veya zayıf olduğu alanlarda kayıp daha fazladır. Ayrıca arazi kullanımının değişimi de menderes karakteristiklerini ve morfolojisini olumsuz olarak etkilemektedir (Hasfurther, 1985).

Son olarak insan etkisi üzerinde durmak yerinde olacaktır. Yerleşime elverişli olmayan yüksek dağlık alanlarda insan faktörünün olumsuz etkisi daha az şekilde gerçekleşirken, alçak plato ve taşkın ovalarında bu etkiler daha fazladır (Ekinci, 2004). Bunun yanında bu sahada gerçekleştirilen yoğun pirinç tarımı ve bu tarıma bağlı çok fazla miktarda su kullanımı (Özşahin, 2008) akarsuyun akımında çok ciddi düşüşler yaşanmasına neden olmaktadır. Bu durum mendereslenme süreçlerinin yavaşlamasına ortam hazırlamaktadır.

\section{BULGULAR ve TARTIŞMA}

Bu bölümde Gönen Çayı́nın morfometrik özellikleri, kıvrımlık indeksi ve mendereslenme oranı saptanmış ve bu verilere bağı olarak mendereslenme özellikleri hakkında değerlendirmeler yapılmıştır.

\section{Morfometrik Özellikler}

Topografyadaki yerşekilleri ve buna bağı olarak yer sistemlerinin anlaşılmasında anahtar analizler olarak betimlenen çalışmaları kapsayan morfometrik veriler, yeryüzündeki topografik durumunun matematiksel özelliklerinin belirlenmesine yardımcı olmaktadır (Tarı ve Tüysüz, 2008; Yıldırım ve Karadoğan, 2011; Koç, 2013). Son yıllarda morfometrik çalışmalar, Coğrafi Bilgi Sistemleri (CBS) ve Sayısal Yükseklik Modeli (SYM/DEM) kullanılarak rakamsal sorgulamaların (Özdemir ve Bahadır, 2008: Bahadır ve Özdemir, 2011) ve analizlerin (Hirano vd., 2002; Demirkesen, 2003; Akar, 2007) kolaylıkla 
gerçekleştirilebildiği bir durum kazanmıştır. Böylece röliyefe ait morfometrik parametreler yardımıyla herhangi bir alandaki jeomorfolojik oluşum ve gelişim daha sağlıklı bir şekilde açıklanabilmektedir (Erginal ve Cürebal, 2007).

Gönen Çayı'nın yaptığı mendereslenmelerin daha iyi tahlil edilmesi için ilgili literatürde de bahsedildiği üzere (Hasfurther, 1985) mendereslenme kuşağı özellikleri dikkate alınarak akarsuyun etrafına 1000 m’lik buffer atılmış ve bu sahanın içerisinde kalan alanların morfometrik özellikleri açıklanmıştır. Bu bağlamda yükselti ve eğim özelliklerinin içinde bulunduğu havza röliyefi, engebelilik değeri, hipsometrik eğri ve hipsometrik integral olmak üzere 4 uygulama indisi kullanılmıştır.

Analiz alanının en yüksek noktası 552 m, en alçak noktası ise deniz seviyesidir. Buna göre sahadaki yükselti farkı 552 m'dir. Bunun yanında ortalama yükselti değeri ise 68.27 m’dir (Şekil 4).
Inceleme sahasındaki eğim değerleri Erol (1993) tarafından yapılan sınıflandırma dikkate alınarak düzlük ve yamaç olarak ayrılmıştır (Şekil 5). Düzlükler \% 0-2 (Düzlük) ve \% 2.01-5 (Dalgalı düzlük), yamaçlar ise \% 5.01-10 (Az eğimli yamaç), \% 10.01-40 (Eğimli dik yamaç) ve \% 40.01-+ (Çok dik yamaç) eğim sınıfları ile temsil edilmektedir (Tablo 1). Buna göre inceleme alanında eğim sınıfları genellikle eğimli dik yamaçlarla temsil edilmektedir (Şekil 4; Tablo 1). Eğim değerleri M1, M2, M3, M4, M5, M6, M12, M13, M14, M15 ve M16 numaraları mendereslerde yüksek, diğerlerinde ise oldukça düşüktür. Yüksek eğimin olduğu menderesler jeomorfolojik olarak Gönen Çayı'nın kuzey ve güney boğazına karşılık gelmektedir. Buradaki menderesler, boğazın sürempozisyon mekanizmasıyla oluşumu düşünüldüğünde (Kantürer, 1993) saplanmış gömük mendereslerdir. Bu nedenle yüksek eğim değerleri gösterirler.

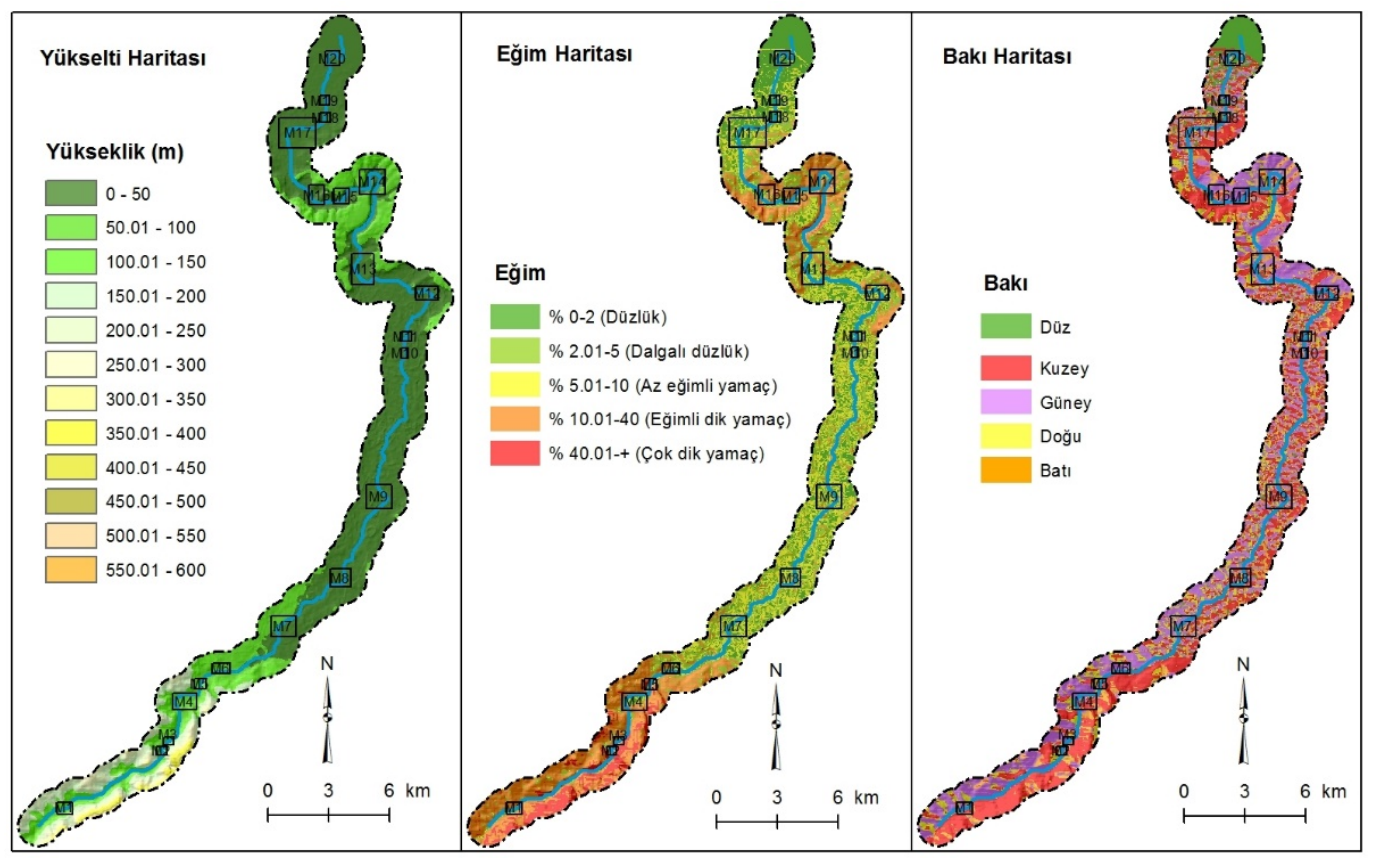

Şekil 4. Analiz alanın yükseklik, eğim ve bakı haritaları.

Figure 4. Altitude, slope and aspect maps of analysis the area.

Tablo 1. Analiz alanındaki eğim ve bakı sınıflarının dağılışı.

Table 1. The distribution of slope and aspect classes of analysis the area.

\begin{tabular}{|c|c|c|c|c|c|c|c|c|c|c|}
\hline \multirow[t]{2}{*}{ Eğim } & \multicolumn{2}{|c|}{$\begin{array}{c}\% 0-2 \\
\text { (Düzlük) }\end{array}$} & \multicolumn{2}{|c|}{$\begin{array}{c}\text { \% 2.01-5 } \\
\text { (Dalgalı düzlük) }\end{array}$} & \multicolumn{2}{|c|}{$\begin{array}{c}\% \text { 5.01-10 } \\
\text { (Az eğimli yamaç) }\end{array}$} & \multicolumn{2}{|c|}{$\begin{array}{c}\% \text { 10.01-40 } \\
\text { (Eğimli dik yamaç) }\end{array}$} & \multicolumn{2}{|c|}{$\begin{array}{c}\text { \% 40.01-+ } \\
\text { (Çok dik yamaç) }\end{array}$} \\
\hline & $24.48 \mathrm{~km}^{2}$ & $\% 19.32$ & $31.86 \mathrm{~km}^{2}$ & $\% 25.14$ & $25.58 \mathrm{~km}^{2}$ & $\% 20.19$ & $37.88 \mathrm{~km}^{2}$ & $\% 29.89$ & $6.92 \mathrm{~km}^{2}$ & $\% 5.46$ \\
\hline \multirow{2}{*}{ Bakı } & \multicolumn{2}{|c|}{ Düz } & \multicolumn{2}{|c|}{ Kuzey } & \multicolumn{2}{|c|}{ Güney } & \multicolumn{2}{|c|}{ Doğu } & \multicolumn{2}{|c|}{ Batı } \\
\hline & $7.83 \mathrm{~km}^{2}$ & $\% 6.18$ & $45.61 \mathrm{~km}^{2}$ & $\% 35.99$ & $43.04 \mathrm{~km}^{2}$ & $\% 33.96$ & $16.02 \mathrm{~km}^{2}$ & $\% 12.64$ & $14.22 \mathrm{~km}^{2}$ & $\% 11.22$ \\
\hline
\end{tabular}

Topografya'daki bakı özellikleri kullanılarak, jeomorfolojik aşınım döngüsündeki aşama ve topografyanın oluşumu hakkında da fikir sahibi olunabilmektedir (Ekinci, 2004). Bakı özellikleri özellikle topografyadaki yönlenmeyi göstermektedir. Analiz alanındaki bakı sınıfları 4 ana yön ve düz alanlar dahil olmak üzere toplamda 5 farklı sınıfta toplanmıştır (Tablo 1). Bu bakımdan değerlendirildiğinde sahada genel olarak \% 35. 99 oranıla kuzeye bakan bir pozisyon hakimdir (Şekil 4; Tablo 1).
Havzanın en yüksek noktası ile en alçak noktası arasındaki maksimum dikey uzaklığı farkı ifade eden (Özdemir, 2011), havza röliyefi değeri, yüksek olduğu durumlarda daha eğimli ve dik yamaçlarla temsil edilen bir topografyanın varlığına işaret eder. Havza röliyefi değeri, havzanın en yüksek ve en alçak noktaları arasındaki farkın alınmasını gösteren aşağıdaki formüle göre hesaplanır.

$$
B_{h}=H_{\max }-H_{\min }
$$


Bu formülde; $B_{h}$ : Havza röliyefi, $H_{\text {max }}$ : Havzanın en yüksek noktası (m) ve $H_{\text {min }}$ : Havzanın en alçak noktası (m)'na karşılık gelir. Analiz alanında havza röliyefi değeri 552 m'dir. Bu değer en alçak nokta olan deniz seviyesi ve menderes oluşumu esas alındığında oldukça yüksek bir rakamdır. Bu durum tıpkı eğim özelliklerinde olduğu şekilde eğimli bir topografyanın analiz alanında egemen olduğunu gösterir.

Bir diğer morfometrik indis değeri olan engebelilik, topografyanın genel karakteri ve yarılma derecesi arasındaki ilişkiyi ortaya koymaktadır. Bu bakımdan yüksek oranda yarılmış araziler alçak, daha az yarılmış ve engebeli araziler ise yüksek röliyef özellikleri gösterirler. Ayrıca engebelilik değerinin artışına bağlı olarak akarsuların erozif faaliyetlerinin hızı da artmaktadır. Bu değer havza röliyefi ve drenaj yoğunluğunun çarpılmasıyla tespit edilmektedir (Özdemir, 2011) ve aşağıdaki formüle göre hesaplanır.

$$
R_{n}=B_{h} \times D_{1}
$$

Bu formülde; $R_{n}$ : Engebelilik değeri, $B_{h}$ : Havza röliyefi $(\mathrm{km})$; $D_{d}$ : Drenaj yoğunluğu $\left(\mathrm{km} / \mathrm{km}^{2}\right)$ değerlerini göstermektedir. Analiz alanında engebelik değerlerinin 0.59 olup, akarsuların erozif faaliyetlerinin belirgin olduğunun alameti olarak değerlendirilebilir.

Analiz alanında değişik yükselti kademeleri arasındaki oranları daha belirgin ve jeomorfoloji ile daha uyumlu bir şekilde ifade etmek için hipsografik (hipsometrik) eğriler kullanılabilir (Özdemir, 2007). Böylece sahanın genel jeomorfolojik özelliklerinden yükselti katlarının alansal dağılışı belirlenebilir, ana jeomorfolojik birimler tespit edilebilir ve aşınım yüzeylerinin genel karakteri ortaya çıkarılabilir (Ekinci, 2011).

Hipsografik eğrinin elde edilmesinde iki farklı yöntem vardır. Bunlardan ilki Strahler (1952) tarafından ortaya konulmuştur. Bu metot, toplam havza yükseltisinin, toplam havza alanı ile olan ilişkisi esasına dayanmakta ve hipsografik eğri ise nispi yükselti $(h / H)$ ve nispi alanın $(a / A)$ tespit edilmesi ile ortaya konulmaktadır. Burada " $\mathrm{h}$ " ilgili yükselti seviyesine ait yükselti değeri $(m)$, " $H$ " ise havzanın en yüksek noktasına ait değerdir (Ekinci, 2011). "a" ilgili yükselti seviyesine ait yüzölçümü alanı $\left(\mathrm{m}^{2}\right)$, " $A$ " ise havzanın $\mathrm{m}^{2}$ olarak toplam yüzölçümü alanıdır. Analiz alanının uygulamadaki yükseklik aralığı $50 \mathrm{~m}$ olarak alınmış ve buna göre hipsometrik eğrisi oluşturulmuştur (Tablo 2; Şekil 5). Alansal değerler GDEM yükseklik verisinden elde edilmiş olup, iz düşüm alanı değil, yüzey alanı kullanılmıştır.

Formül içeriği doğrultusunda elde edilen hipsometrik eğriden sahanın aşınım döngüsü bakımından derecesi elde edilebilmektedir. Bunun yanında kayaçların direnç özellikleri, ani litolojik değişimler morfolojik ötelenme ve kapmalarda hipsometrik eğriler üzerinde anomaliler olarak izlenebilmektedir (Tarı ve Tüysüz, 2008).

Hipsometrik eğrinin 1 ve ona yakın olan kısımları henüz yeni oluşmuş yüzeylere işaret etmektedir. Değerin orta ve düşük çıkması topografyanın olgun veya yarı olgun bir aşınım döneminde olduğunu göstermektedir (Tarı ve
Tüysüz, 2008; Özdemir, 2011). Çok düşük eğri değerleri ise tepelik ve dağlık alanların varlığına işaret etmektedir. Ayrıca bu eğriden jeomorfolojik görünümde değişikliklere neden olan süreçler hakkında da bazı genel değerlendirmeler yapılabilmektedir (Ekinci, 2011).

Tablo 2. Analiz alanındaki yükselti basamaklarının dağılışı ve hipsometrik eğri için veri değerleri.

Table 2. The distribution of elevation of analysis the area and the data values for hypsometric curve.

\begin{tabular}{ccrccc}
\hline $\begin{array}{c}\text { Yükseklik } \\
\text { (h) }\end{array}$ & $\begin{array}{c}\text { Maksimum } \\
\text { Yükseklik } \\
\text { (H) }\end{array}$ & $\begin{array}{c}\text { Alan (a) } \\
\text { (Yüzey Alanı } \\
\mathbf{m}^{\mathbf{2}} \text { ) }\end{array}$ & $\begin{array}{c}\text { Havza Alanı } \\
\text { (Yüzey Alanı) } \\
\text { (A) } \mathbf{~ m}^{\mathbf{2}}\end{array}$ & $\begin{array}{c}\text { Rölatif } \\
\text { Yükseklik } \\
\text { (h/H) }\end{array}$ & $\begin{array}{c}\text { Rölatif } \\
\text { Alan } \\
\text { (a/A) }\end{array}$ \\
\hline 0 & 552 & 126961295.49 & 126961295.49 & 0.00 & 1.00 \\
50 & 552 & 52498190.46 & 126961295.49 & 0.09 & 0.41 \\
100 & 552 & 28421877.76 & 126961295.49 & 0.18 & 0.22 \\
150 & 552 & 17905707.59 & 126961295.49 & 0.27 & 0.14 \\
200 & 552 & 10688221.43 & 126961295.49 & 0.36 & 0.08 \\
250 & 552 & 5749890.45 & 126961295.49 & 0.45 & 0.05 \\
300 & 552 & 3153457.12 & 126961295.49 & 0.54 & 0.02 \\
350 & 552 & 1831584.34 & 126961295.49 & 0.63 & 0.01 \\
400 & 552 & 937902.74 & 126961295.49 & 0.72 & 0.01 \\
450 & 552 & 420988.40 & 126961295.49 & 0.82 & 0.00 \\
500 & 552 & 98579.37 & 126961295.49 & 0.91 & 0.00 \\
552 & 552 & 3.31 & 126961295.49 & 1.00 & 0.00 \\
\hline
\end{tabular}

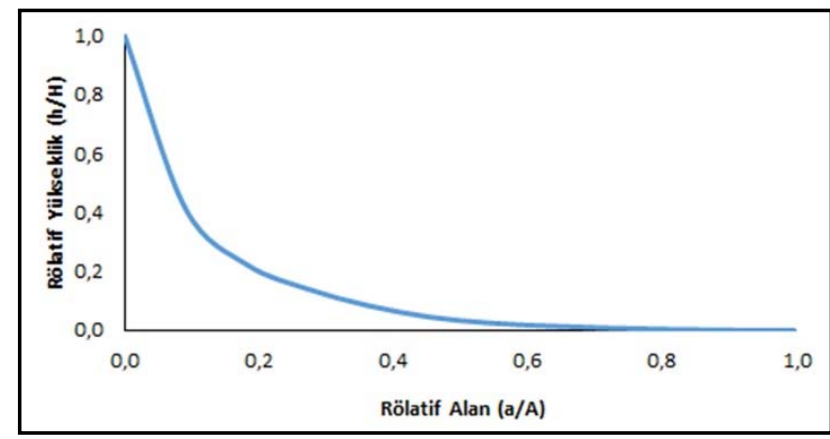

Şekil 5. Analiz alanının hipsometrik eğrisi.

Figure 5. Hypsometric curve of of analysis the area.

Buna göre analiz alanının hipsometrik eğrisinde genellikle iç bükey (konkav) bir durum hakimdir. Bu durum analiz alanının Strahler (1954) tarafından bildirilen sertgen evresine (Strahler, 1973) denk gelen olgun bir topografya döneminde olduğunu göstermektedir.

Hipsometrik integral, hipsometrik eğri altında kalan toplam alan olup, analiz alanı için hipsometrik eğriyi karakterize etmenin en basit yollarından birisidir (Özdemir, 2007). Hipsometrik integral, ortalama ve minimum yükseklik arasındaki farkın, maksimum ve minimum yükseklik arasındaki farka oranlanmasıyla elde edilmektedir (Ekinci, 2011).

Elde edilen değere göre analiz alanı, aşınım döngüsü bakımından olgunluk devresindedir. Bunun yanında dış kuvvetler ve özellikle de akarsular tarafından gerçekleştirilen aşındırma, taşıma ve biriktirme faaliyetlerinin hâlâ etkili olduğu anlaşılmaktadır (Şekil 6).

\section{Kıvrımlılık İndeksi}

Bir akarsuyun yavaş bir şekilde menderesler çizerek akması veya kıvrımlı bir yatak şekli oluşturması, flüvyal aşınmanın son safhasında veya alt mecrada meydana gelen 
bir olaydır (Atalay, 1986). Bir akarsuyun yavaş bir şekilde menderesler çizerek akması veya kıvrımlı bir yatak şekli oluşturması, flüvyal aşınmanın son safhasında veya alt mecrada meydana gelen bir olaydır (Atalay, 1986). Yapılan araştırmalar, mendereslenmenin yatağını düzenleyen akarsuların hareketi sonucunda meydana geldiğini ortaya koymuştur (Leopold ve Wolman, 1957; Hasfurther, 1985; Atalay, 1986; Bridge, 1993). Zira menderesli akarsular eğim değerlerinin son derece az, zaman zaman taşkınlara maruz kalan, yatak yükünden çok asılı haldeki malzemelerin taşındığı, yeraltı suyu seviyesinin yüksek olduğu, zaman zaman akarsuyun yeraltı suyu akımı ile beslendiği ve akarsu faaliyetlerinin son dönemini yaşadığı yerlerde yaygın olarak görülmektedir (Atalay, 1986). Bununla birlikte akarsuların taşkın ovalarında sürekli menderesler resmederek aktığı da doğru değildir (Erinç, 2012). Bu nedenle bir akarsuyun ne kadar menderesli olduğunu ortaya koymak için kıvrımlık indeksinden faydalanılır (Şekil 7; 8).

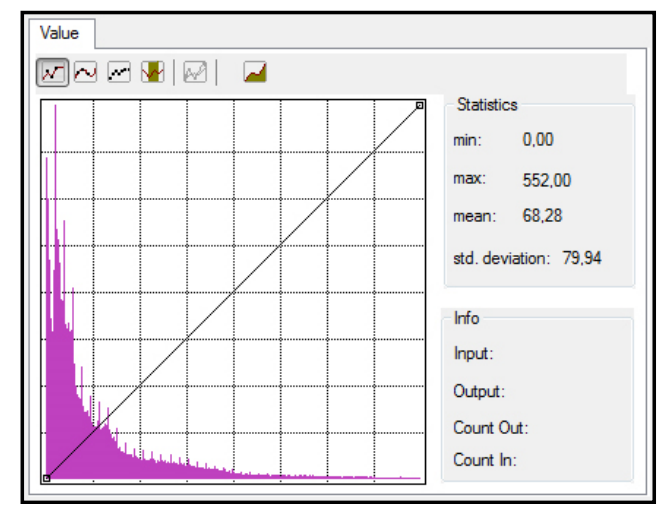

Şekil 5. Analiz alanına ait histogram.

Figure 5. Histogram of analysis the area.

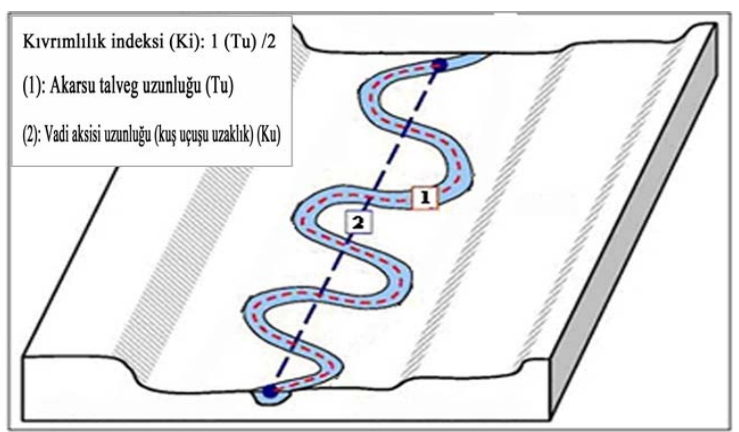

Şekil 7. Kıvrımlık indeksinin hesaplanması (Watershed Protection Department (2013)'dan değiştirilerek).

Figure 7. Calculating the value of sinuosity (Changed from Watershed Protection Department (2013)).
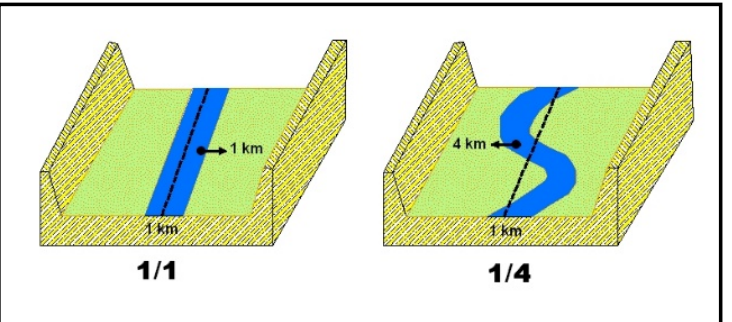

Şekil 8. Düz ve iyi gelişmiş bir menderesli akarsu kanalı (The British Geographer (2013)'den değiştirilerek).

Figure 8. Flat and well-developed meandering river channel (Changed from The British Geographer (2013)).
Kıvrımlık indeksi, akarsu vadisinin ortasından geçen bir hat uzunluğu ile akarsuyun yatakla temas eden kısmının uzunluğunun (talveg uzunluğu) birbirine oranı şeklinde ifade edilmekte ve düz bir hattan menderes sapmaları ile meydana gelen genişlemeyi göstermektedir. Kıvrımlık indeksi, akarsu yatağında akış hızının maksimum olduğu kısmın uzunluğunun, vadi uzunluğuna bölünmesi sonucunda elde edilmektedir (Mueller, 1979; Zavoıanu, 1985; Şekil 7; 8). Bu bakımdan bir akarsu 1/1.5 kıvrımlık indeksini aşarsa, menderesli bir karakter taşıdığı söylenebilir (Leopold ve Wolman, 1957; Hasfurther, 1985; Doğan, 2012).

Aslında akarsu kıvrımlık indeksi, topografik ve hidrolik kıvrımlılık indeksi olarak ikiye ayrılmaktadır (Şekil 9). Topografik kıvrımlılık indeksi, spesifik bölgelerdeki jeomorfolojik gelişimin ilk aşamalarındaki yüksek röliyef enerjisini, hidrolojik kıvrımlılık indeksi ise genellikle düz sahalarda olgunluğa ulaşmış röliyefteki akarsu etkinliğini belirlemede kullanılmaktadır. Bu bağlamda topografik kıvrımlılık indeksinden daha çok saplanmış gömük mendereslerin, hidrolojik kıvrımlılık indeksinden de taşkın ovalarındaki mendereslerin kıvrımlanma oranın tespit edilmesinde yararlanılmaktadır. Ancak günümüze kadar yapılan birçok çalışmada topografik ve hidrolik kıvrımlılık indeksleri tek olarak kullanılmaktadır. Zira bu iki tip arasındaki ayrımda çok detaylı yerel çalışmalarda ortaya çıkmaktadır (Zavoıanu, 1985).

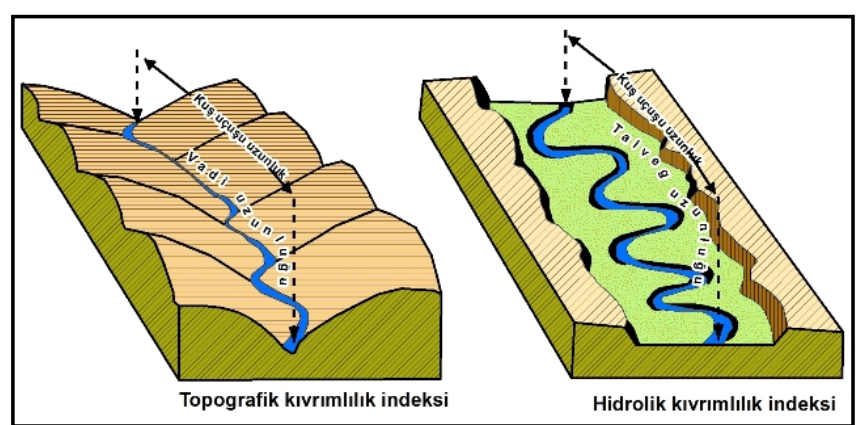

Şekil 9. Kıvrımlılık indeksinin hesaplanmasında kullanılan yöntemler (Zavoıanu, 1985'ten yeniden çizilerek).

Figure 9. The methods used to calculate the rate of sinusitis (redraws from Zavoıanu, 1985).

$\mathrm{Bu}$ çalışmada bundan önce yapılan benzer çalışmalarda olduğu gibi kıvrımlılık indeksi ayrım yapılmadan tek olarak değerlendirilmiştir. Esasında ise Gönen Çayı'nın aşağı havzasındaki taşkın ovasında meydana getirdiği mendereslerin kıvrımlılık özellikleri incelendiği için hidrolik kıvrımlılık indeksi değeri kullanılmıştır. Buna göre hidrolik kıvrımlılık indeksi vadi aksisi (kuş uçuşu uzaklık) uzunluğunun (Lv), akarsu kanal uzunluğuna (LC) oranı olarak saptanmaktadır. "Hs = Lv/Ls" formülü ile ifade edilmektedir (Zavolanu, 1985).

Inceleme alanında Gönen Çayı'nın akarsu kanal uzunluğu (LC) 75 km, vadi aksisi uzunluğu (kuş uçuşu uzaklık) (Lv) 42 km'dir. Buna göre kıvrımlılık indeksi ise 1/1.7 (0.5)'dir. Kıvrımlılık indeksine göre Gönen Çayı, aşağı akaçlama havzasında menderesli bir karakter taşımaktadır. 
Gönen Çayı'nın mendereslenme morfolojisi ve mendereslenmeyi etkileyen faktörler

\section{Mendereslenme Oranı}

Akarsuların yaptığı menderesler ve akarsu jeomorfolojisinin kanunları arasında var olan ilişkiye dayanan matematiksel analiz yöntemleri giderek artmaktadır (Parker, 1976; Goudie, 2004). Buna göre mendereslenme oranı akarsuların sahip olduğu yatak genişlikleri ile menderes kuşakları arasındaki bağlantıyı ifade etmektedir. Bu oranın dünyanın büyük akarsularında (Missisippi, Rhein, Po ve Tuna vs. gibi) yaklaşık 1/18 (Erinç, 2012), Türkiye'deki Meriç Nehrinin farklı kısımlarında 1/10, $1 / 17$ ve $1 / 20$ gibi değerler gösterdiği belirlenmiştir (Göçmen, 1999).

Mendereslenme oranının tespit edilmesinde, menderes oluşturan akarsuların sahip oldukları çeşitli fonksiyonların bir sonucu olarak (Şekil 10) menderes uzunluğu, menderes amplitüdü, ortalama menderes çapı, kanal genişliği ve yük arasındaki ilişkileri ortaya koyan Leopold ve Wolman (1960) tarafından geliştirilen formül dikkate alınmıştır (Göçmen, 1999).

$$
\begin{array}{ll}
\begin{array}{l}
\text { Bu formül; } \\
L=10.9 w^{1.01}
\end{array} & L=\text { Menderes uzunluğu, } \\
A=2.7 w^{1 \cdot 1} & A=\text { Menderes kuşağı genişliği, } \\
L=4.7 r_{m}^{0.98} & W=\text { Mecra genişliği, } \\
& r_{m}=\text { Menderes büklümü yarıçapını }
\end{array}
$$

ifade etmektedir.

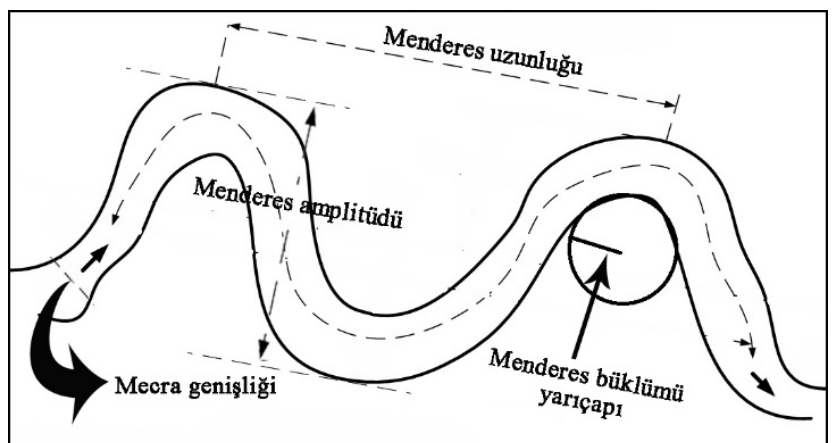

Şekil 10. Menderesli bir akarsuyun geometrik özellikleri (Khatsuria, 2008'den değiştirilerek).

Figure 10. Geometric features of a stream meandering (Changed from Khatsuria, 2008).

$\mathrm{Bu}$ yaklaşım göz önünde bulundurularak yapılan hesaplamaya göre, Gönen Çayı́nın aşağı akaçlama havzasında 20 adet menderes büklümü yaptığı ve ortalama mendereslenme oranının ise 14 olduğu tespit edilmiştir (Tablo 3; Şekil 11; Fotoğraf 2; 3; 4; 5).

Gönen Çayı'nın mendereslenme oranının en yüksek değeri (45) M 14 numaralı mendereste tespit edilmiştir (Şekil 11). Bu menderes büklümü Gönen Çayı kuzey boğazında yer almakta olup, saplanmış gömük menderes karakterinde gelişmiştir. Başta jeoloji ve jeomorfoloji olmak üzere mendereslenmeyi etkileyen faktörlerin uygunluğuna

\begin{tabular}{|c|c|c|c|c|c|c|c|}
\hline Mecra No & $\begin{array}{l}\text { Formül } \\
\text { Sonucu } \\
(\mathrm{m})\end{array}$ & $\begin{array}{l}\text { Haritadan } \\
\text { Ölsülen } \\
(\mathrm{m})\end{array}$ & $\begin{array}{l}\text { Mendereslenme } \\
\text { Oranı }\end{array}$ & $\begin{array}{c}\text { Mecra } \\
\text { No }\end{array}$ & $\begin{array}{l}\text { Formül } \\
\text { Sonucu } \\
(\mathrm{m})\end{array}$ & $\begin{array}{l}\text { Haritadan } \\
\text { Öıçülen } \\
(\mathrm{m})\end{array}$ & $\begin{array}{l}\text { Mendereslenme } \\
\text { Oranı }\end{array}$ \\
\hline & $\mathrm{L}=163.5$ & 1100.6 & & & $\mathrm{~L}=141.7$ & 770.6 & \\
\hline \multirow[t]{2}{*}{ M1 } & $A=40.5$ & 183 & 12 & M 11 & $A=35.1$ & 186 & 14 \\
\hline & $\begin{array}{l}L=940 \\
L=152.6\end{array}$ & $-\frac{1100.6}{712.4}$ & - & & $-\mathrm{L}=\frac{517}{\mathrm{~L}}=141.7$ & $-\frac{770.6}{1530.4}$ & ------ \\
\hline \multirow[t]{2}{*}{ M2 } & $A=37.8$ & 167 & 12 & M 12 & $A=35.1$ & 310 & 24 \\
\hline & $\begin{array}{l}\mathrm{L}=470 \\
\mathrm{~L}=152.6\end{array}$ & $-\frac{712.4}{610}$ & 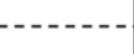 & & $-\mathrm{L}=907.1$. & $-\frac{1530.4}{2307.9}$ & $-\cdots$ \\
\hline \multirow[t]{2}{*}{ M 3} & $A=37.8$ & 125 & 9 & M 13 & $A=48.6$ & 455 & 25 \\
\hline & $\begin{array}{l}\mathrm{L}=446.5 \\
\mathrm{~L}=185.3\end{array}$ & $-\frac{6}{17} \frac{10}{48.2}$ & & & $\begin{aligned} L & =1645 \\
L & =174.4\end{aligned}$ & $-\frac{2307.9}{2759.1}$ & \\
\hline \multirow[t]{2}{*}{ M4 } & $A=45.9$ & 337 & 20 & M 14 & $A=43.2$ & 725 & 45 \\
\hline & $\begin{array}{l}\mathrm{L}=1621.5 \\
\mathrm{~L}=207.1\end{array}$ & $--\frac{1748.2}{821.6}$ & & & $-L=705-$ & $-\frac{2759.1}{1163.5}$ & ------1 \\
\hline \multirow[t]{2}{*}{ M 5} & $A=51.3$ & 170 & 9 & M 15 & $A=48.6$ & 235 & 13 \\
\hline & $\begin{array}{l}\mathrm{L}=564 \\
\mathrm{~L}=185.3\end{array}$ & $-\frac{821.6}{1153.5}$ & ----- & & $\begin{array}{l}\mathrm{L}=8993- \\
\mathrm{L}=327\end{array}$ & $-\frac{11}{13} 635.5$ & -----1 \\
\hline \multirow[t]{2}{*}{ M 6} & $A=45.9$ & 211 & 12 & M 16 & $A=81$ & 267 & 9 \\
\hline & $\begin{array}{l}\mathrm{L}=987 \\
\mathrm{~L}=218\end{array}$ & $-\begin{array}{r}1153.5 \\
1661\end{array}$ & & & $\begin{array}{l}\mathrm{L}=1269 \\
\mathrm{~L}=305.2\end{array}$ & $-\frac{1335.4}{2618.3}$ & ----1 \\
\hline M7 & $A=54$ & 249 & 12 & M 17 & $A=75.6$ & $\begin{array}{r}20.3 \\
576\end{array}$ & 21 \\
\hline \multicolumn{2}{|c|}{$------\frac{L}{L}=1480.5$} & $-\frac{1661}{1318.4}$ & 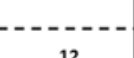 & & $\begin{array}{ll}L & =2350 \\
L & =185.3\end{array}$ & $-\frac{2618.3}{791.3}$ & ------ \\
\hline M 8 & $A=70.2$ & 300 & & M 18 & $A=45.9$ & 200 & \\
\hline & $\begin{array}{l}\mathrm{L}=1175 \\
\mathrm{~L}=294.3\end{array}$ & $-\frac{1318.4}{1502.7}$ & & & $-L=507.6$ & $--\frac{791.3}{579.6}$ & ------ \\
\hline M9 & $A=72.9$ & 288 & 11 & M 19 & $A=78.3$ & 141 & 5 \\
\hline & $\begin{array}{l}\mathrm{L}=1847.1 \\
\mathrm{~L}=152.6\end{array}$ & $-\frac{1502.7}{603.2}$ & & & $L=672.1$ & $--\frac{579.6}{1217.2}$ & ---- \\
\hline M 10 & $A=37.8$ & 97 & 7 & M 20 & $A=91.8$ & 326 & 10 \\
\hline & $L=780.2$ & 603.2 & & & $L=822.5$ & 1217.2 & \\
\hline
\end{tabular}
bağıı olarak en büyük oranı yakalamıştır.
Tablo 3. Gönen Çayı'nın menderesleri ve mendereslenme oranları.

Table 3. Meanders of Gönen Creek and ratio of meander.

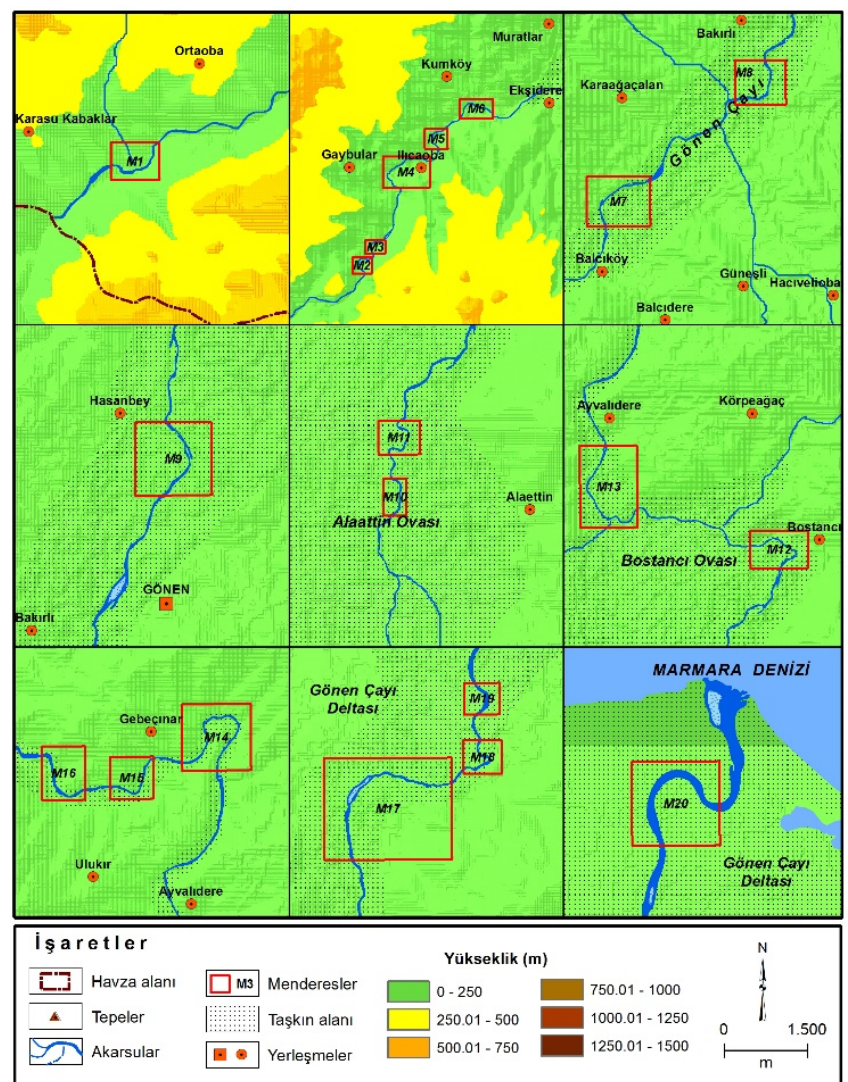

Şekil 11. Gönen Çayı'nın aşağı mecrasında yaptığ mendereslerin konumları.

Figure 11. Gönen Creek that location of meanders in the sub-basin. 


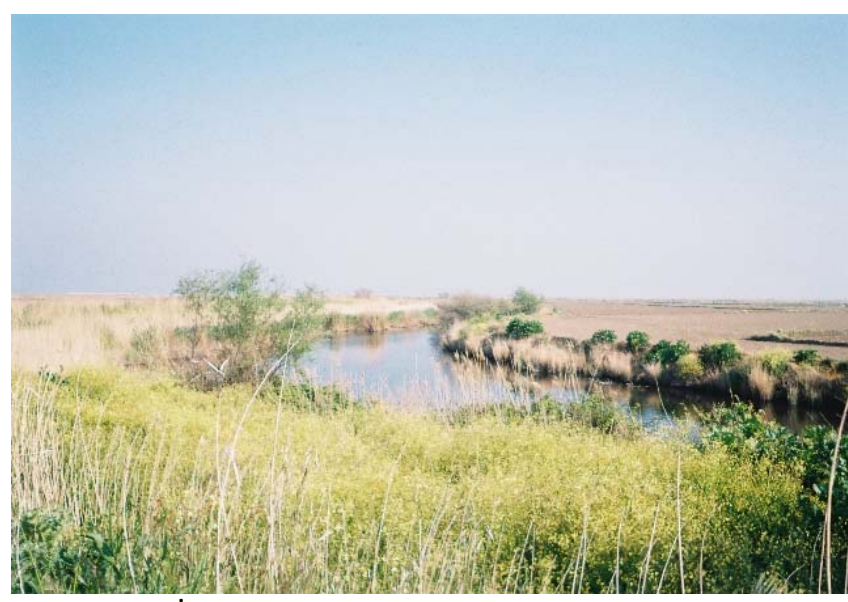

Fotoğraf 2. İnceleme alanında görülen menderesler. Foto 2. Meanders in the study area.

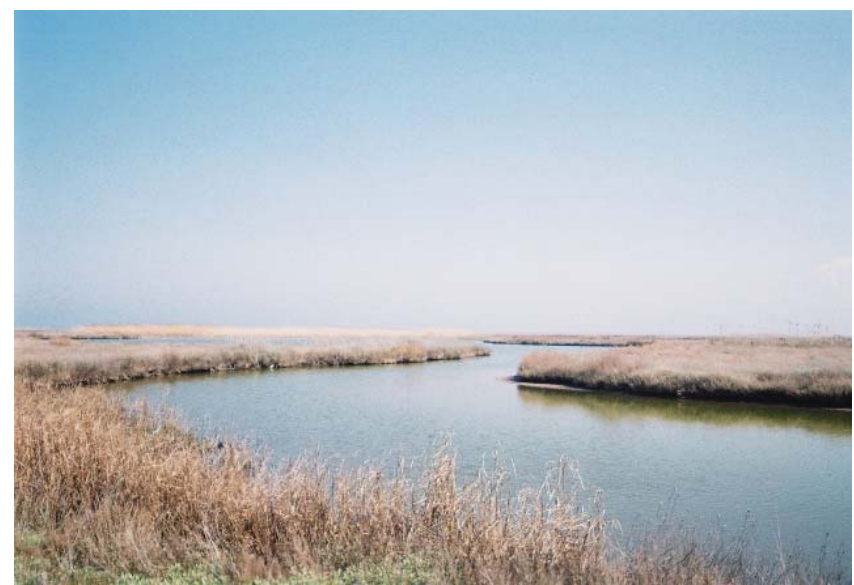

Fotoğraf 3. İnceleme alanında görülen menderesler.

Foto 3. Meanders in the study area.

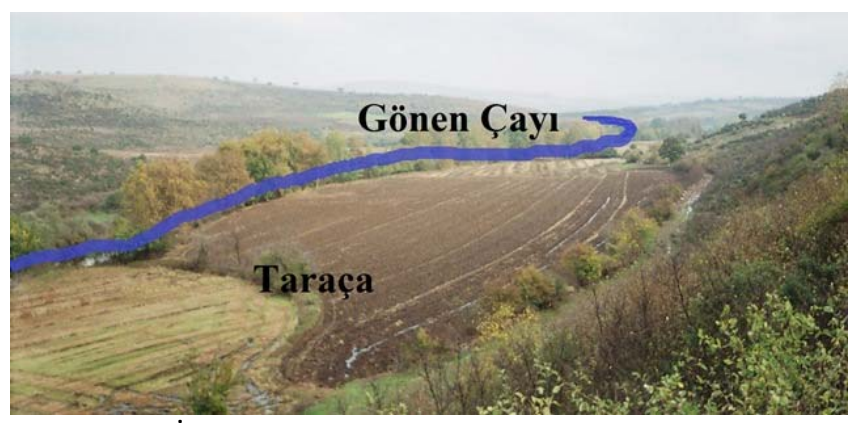

Fotoğraf 4. İnceleme alanında görülen menderesler.

Foto 4. Meanders in the study area.

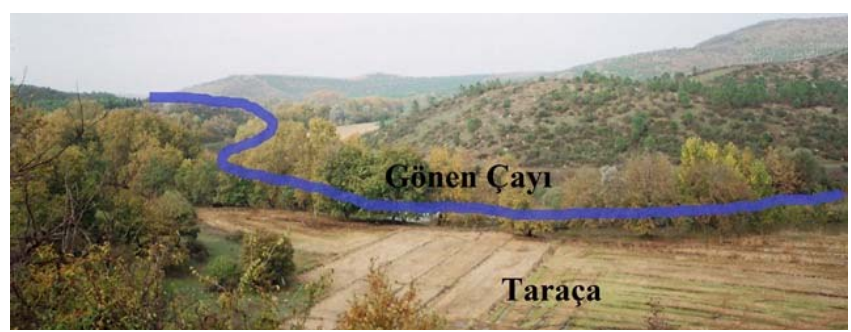

Fotoğraf 5. İnceleme alanında görülen menderesler.

Foto 5. Meanders in the study area.

Gönen Çayı'nın mendereslenme oranının en yüksek değeri (45) M 14 numaralı mendereste tespit edilmiştir (Şekil 11).
Bu menderes büklümü Gönen Çayı kuzey boğazında yer almakta olup, saplanmış gömük menderes karakterinde gelişmiştir. Başta jeoloji ve jeomorfoloji olmak üzere mendereslenmeyi etkileyen faktörlerin uygunluğuna bağlı olarak en büyük oranı yakalamıştır.

Jeomorfolojik olarak en yüksek mendereslenmenin görüldüğü sahada (Gönen Çayı kuzey boğazı) yer alan M 15 (13) ve M 16 (9) numaralı mendereslerde ise menderesle oranı ortalamanın altındadır.

Gönen Çayı́nın Gönen Ovası'na girdiği bölgede yapmış olduğu mecrada (M 1) menderes uzunluğu, genişliği, çapı ve menderes kuşağı genişliği arasındaki ilişkiler formül neticelerinden oldukça farklı bir özellik göstermektedir.

Bu mecradan sonra gelen mecralarda da (M 2, M 3, M 4, M 5) menderes uzunluğu, menderes kuşağı genişliği, mecra genişliği arasındaki ilişkiler birbirine yakın ya da aynı değerleri gösterirken, menderes çapı haritadan ölçülen değerleri, menderes uzunlukları ise farklı değerleri belirtmektedir.

Gönen ilçe merkezinin kuzeyine doğru gelişmiş mecralarda ise ( $M$ 10, M 11, M 12) menderes uzunluğu ile mecra genişliği arasında açık bir bağlantının olduğunu, bunun aksine menderes kuşağı genişliği, menderes çapı, uzunluğu ve mecra genişliği arasındaki ilişkilerin de farklı olduğunu göstermiştir. Ayrıca aynı bölgede yer alan mecralardan ( $M$ 12, M 13) bazılarının formül sonucu hesaplanan menderes uzunluklarının, menderes kuşağı genişliklerinin ve mecra genişliklerinin eşit olduğu tespit edilmiştir. Ancak bu mecraların haritadan ölçülen değerleri arasında ise önemli farklılıklar mevcuttur.

Gönen Çayı́nın denize dökülmeden önce oluşturduğu delta sahasına girdiği alandan itibaren yer alan mecralar (M $17, M 18, M 19, M 20$ ) arasında mendereslenme bakımından önemli sayılabilecek farklılıklar yoktur. Bunun nedeni eğim ve yükselti değerinin çok fazla oynamaması monoton bir yapı göstermesidir.

Inceleme alanında Gönen Çayı'nın ortalama mendereslenme değeri, 1/14'tür (Şekil 12). Yapılan hesaplamalara göre elde edilen sonuç, Dünya'dan ve Türkiye'den örnekleri verilen akarsulara oranla daha düşüktür. Bu bulgu Gönen Çayı'nın mendereslenme oranının yukarıda mendereslenme oranları örnek olarak verilen akarsular kadar büyük olmadığını kanıtlar özelliktedir.

Ayrıca Gönen Çayı'nın Gönen Ovası'nda yapmış olduğu mendereslerde, formül sonucu elde edilen değerler ile ölçüm sonucu ulaşılan değerler arasında mendereslenme oranları ile mecra genişlikleri bakımından bir uygunluk vardır. Ayrıca menderes kuşağı genişliği ile mecra genişliği arasında $1 / 3^{\prime}$ lük bir oran, buna karşılık ise menderes uzunluğu ile menderes çapı arasında da 2/1'lik bir oran olduğu belirlenmiştir. 


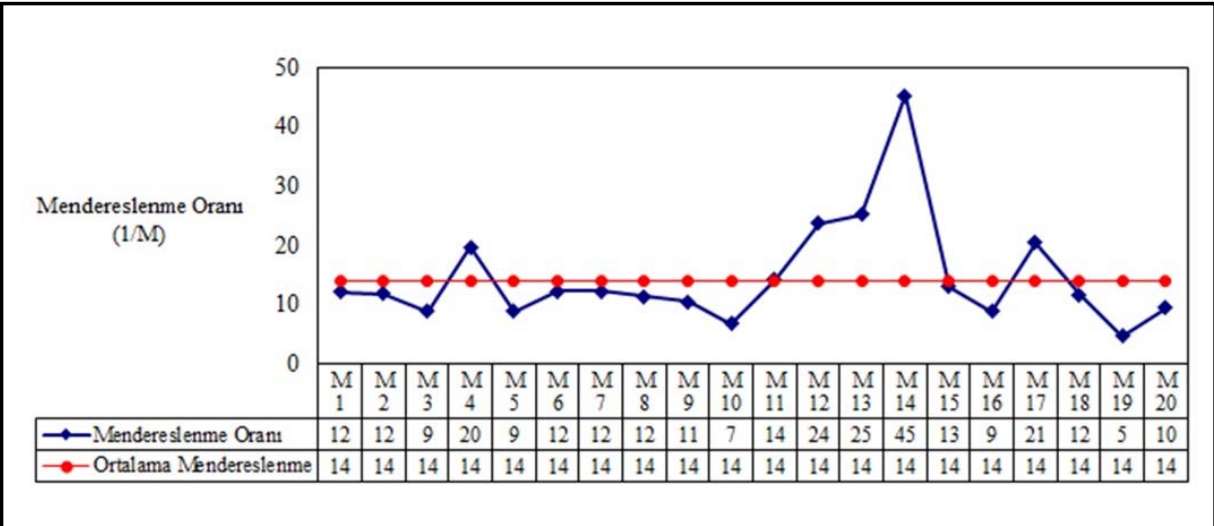

Şekil 12. Gönen Çayı'nın mendereslenme oranı ve ortalama mendereslenme oranı.

Figure 12. Meander ratio of Gönen Creek and average rate of meander.

\section{SONUÇ}

$\mathrm{Bu}$ çalışma mendereslenme üzerinde akarsu havzasının sahip olduğu topografya, jeoloji, jeomorfoloji, hidrografya, iklim, toprak, zemin örtüsü ve insan faktörlerinin etkili olduğunu göstermiştir. Zira bu faktörlere bağlı olarak Gönen Çayı'nın ana akarsu kolunda menderesli kanal şekli gelişmiş ve koşulların uygun olduğu alanlarda ise mendereslerin geometrisi büyümüştür.

Inceleme alanında Gönen Çayı́nın yaptığı mendereslerden saplanmış gömük mendereslerin oluşum aşaması düşünüldüğünde en baskın olarak jeolojik ve jeomorfolojik faktörlerin ağırlığı altında şekillenmiş olduğu anlaşılmaktadır. Ancak diğer mendereslerde ise böyle bir durum söz konusu değildir.

Inceleme alanında eğimin azalmasına bağlı olarak akarsuyun yaptığı mendereslerin az, fakat geniş ve büyük olduğu görülmektedir. Bu sahalarda menderes uzunluğu, menderes kuşağı genişliği, mecra genişliği ve menderes çapı değerleri de büyümektedir. Sahada menderes ebatlarının küçüldüğü kısımlarda meydana gelen küçülme ise, yük boyutları ile olan ilişkiye bağlanabilir. Gönen Ovası'ndaki faylanmalarda mendereslenme özelliklerinde belirleyici olmuştur. Buna göre özellikle M 19 ve M 20 menderesler hariç genel olarak ovadaki bütün menderesler azda olsa tektonik hareketlerin kontrolünde bir konumda yer almaktadır.

Gönen Çayı'nın aşağı mecrasındaki morfometrik özelliklerin değerlendirme sonuçları menderes oluşum ve gelişiminin gerçekleşmesini desteklemiştir. İnceleme alanında Gönen Çayı'nın kıvrımlılık indeksinin 1/1.7 olduğu hesaplanmıştır. Buna göre Gönen Çayı bu sahada menderesli bir karakter taşımaktadır. 20 adet menderes kıvrımının yer aldığı sahadaki ortalama mendereslenme oranı ise 1/14 olarak bulunmuştur. Ancak bu değer her menderes büklümü için farklıdır.

Çalışma sonuçları Gönen Çayı'nın yaptığı mendereslerin az, fakat geniş ve büyük olduğunu göstermektedir. Akarsuyun geometrik özelliklerine ait değerlerin menderes boyutunun arttığı lokasyonlarda büyüdüğü, boyutun azaldığı alanlarda ise muhtemelen yük boyutları ile olan ilişkiye bağlı olarak küçüldüğü tespit edilmiştir.

$\mathrm{Bu}$ sonuçlara dayanılarak ovadaki hâlihazırdaki arazi kullanımının tekrar gözden geçirilerek planlanması gerekmektedir. Bilhassa mendereslerin geometrisinin büyüdüğü sahalarda olası taşkınlara karşı koruma kuşakları yapılmalıdır. Yapılacak bütün uygulamaların sürdürülebilir bir şekilde planlanması insanın doğal ortamdan en yararlı bir şekilde faydalanmasına imkân sağlayacaktır.

\section{KAYNAKÇA}

Akar, ì. (2007). “Jeomorfoloji Analizlerinde Coğrafi Bilgi Sistemleri Tekniklerinin Kullanımı: Kasatura Körfezi Hidrolojik Havzası Örneği", 5. Türkiye Kuvaterner Sempozyumu TURQUA VI, İstanbul Teknik Üniversitesi Avrasya Yerbilimleri Enstitüsü, İstanbul, s.: 1-13.

Aslan, A. (2007). Flüvial environments: Sediments. In: Elias, S. A. (Ed.), Encyclopedia of Quaternary Science. Amsterdam: Elsevier Ltd., pp.: 672-685.

Atalay, İ. (1986). Uygulamalı Hidrografya. İzmir: Ege Üniversitesi Edebiyat Fakültesi Yayınları No: 38.

Atalay, ì. (1994). Türkiye Vejetasyon Coğrafyası. İzmir: Ege Üniversitesi Basımevi.

Atalay, i. (2002). Türkiye'nin Ekolojik Bölgeleri. Ankara: Orman Bakanlığı Yayınları, No: 163.

Bahadır, M. ve Özdemir, M. A. (2011). “Acıgöl Havzası'nın Sayısal Topoğrafik Analiz Yöntemleri ile Morfometrik Jeomorfolojisi", The Journal Of International Social Research 4 (18): 323-344.

Bridge, J. S. (1993). The interaction between channel geometry, water flow, sediment transport and deposition in braided rivers. In: Best, J. L. \& Bristow, C. S. (Eds.), Braided Rivers, London: Geological Society Special Publication, pp.: 13-71.

Dai, W. and Tang H. (2012). "A Mathematical Model of Migration and Expansion of Meander Loops", Journal of Hydrodynamics 22 (2): 214-220.

Demirkesen, A. C. (2003). "Sayısal Yükseklik Modellerinin Analizi ve Sel Basman Alanlarının Belirlenmesi", TUJK 2003 Yılı Bilimsel Toplantısı Poster Bildiri Coğrafi Bilgi 
Sistemleri ve Jeodezik Ağlar Çalıştayı, 24-25-26 Eylül 2003, Konya.

Doğan, U. (2009). Gülşehir-Sahinler Arasında Kızılırmak'ın Uzun Dönemli Sekileri ve Taşkın Ovasının Gelişimi. Ankara: Ankara Üniversitesi BAP Proje No: 06B535804.

Doğan, U. (2011). "Climate-controlled river terrace formation in the Kızılırmak Valley, Cappadocia section, Turkey: Inferred from Ar-Ar dating of Quaternary basalts and terraces stratigraphy", Geomorphology 126: 66-81.

Doğan, U. (2012). Akarsu Süreçleri. İç: Kuvaterner Bilimi (Ed.: Kazancı, N. ve Gürbüz, A.), Ankara: Ankara Üniversitesi Yayınları No: 350, s.: 281-306.

Efe, R. (1986). Gönen Havzasının Jeomorfolojisi. Basılmamış Yüksek Lisans Tezi, İstanbul: İstanbul Üniversitesi Deniz Bilimleri ve Coğrafya Enstitüsü Jeomorfoloji Anabilim Dalı.

Efe, R. (1994). “Biga Yarımadasında Neotektoniğin Jeomorfolojik İzleri”, Türk Coğrafya Dergisi 29: 209-242.

Efe, R. (1995). “Gönen ve Dolaylarında Gözlenen Çevre Sorunlarına Coğrafi Bir Yaklaşım", Marmara Üniversitesi Sosyal Bilimler Enstitüsü Öneri Dergisi 1 (2): 1-12.

EFE, R. (1996). “Gönen ve Çevresinde Coğrafi Şartların Gönen Çayı Rejimine Etkisi", Marmara Üniversitesi Sosyal Bilimler Enstitüsü Öneri Dergisi 6: 119-127.

Efe, R. (1999). “Güney Marmara Bölümü Batısında Toprak Oluşumunu Etkileyen Coğrafi Faktörler ve Toprakların Özellikleri", Türk Coğrafya Dergisi 34: 193-209.

Efe, R., Soykan, A., Cürebal, İ. and Sönmez, S. (2011). "Review of Geomorphological and Neotectonic Features of the Gönen Basin (NW of Turkey)", Elsevier - Procedia, Social and Behavioral Sciences 19: 716-725.

Ekinci, D. (2004). Gülüç Çayı Havzasının Uygulamalı Jeomorfolojisi. Yayınlanmamış Doktora Tezi, İstanbul: İstanbul Üniversitesi Sosyal Bilimler Enstitüsü.

Ekinci, D. (2011). Safranbolu ve Çevresinin Jeomorfoloji Özellikleri, II. Baskı, Titiz Yayınevi, İstanbul.

Erginal, A. E. ve Cürebal, İ. (2007). "Soldere Havzasının Jeomorfolojik Özelliklerine Morfometrik Yaklaşım: Jeomorfik İndisler ile Bir Uygulama", Selçuk Üniversitesi Sosyal Bilimler Enstitüsü Dergisi 17: 203-210.

Erinç, S. (2012). Jeomorfoloji I. Güncelleştirenler: Ahmet Ertek - Cem Güneysu, İstanbul: Der Yayınları, No: 284.

Erol, O. (1993). “Ayrıntılı Jeomorfoloji Haritaları Çizim Yöntemi", İstanbul Üniversitesi Deniz Bilimleri ve Coğrafya Enstitüsü Bülteni, 10: 19-37.

Gilvear, D., Winterbottom, S. and Sichingabula, H. (2000). "Character of channel planform change and meander development: Luangwa River, Zambia", Earth Surface Processes and Landforms 25 (4): 421-436.

Goudie, A. S. (Edited by). (2004). Encyclopedia of Geomorphology. Volume: Two, London: Routledge Ltd.

Göçmen, K. (1999). Aşağı Meriç Vadisi Taşkın Ovası ve Deltasının Alüviyal Jeomorfolojisi. İstanbul: İstanbul Üniversitesi Coğrafya Enstitüsü Yayını: 80.

Gurnell, A. M., Morrissey, I. P., Boitsidis, A. J., Bark, T., Clifford, N. J., Petts, G. E. and Thompson, K. (2006). “Initial adjustments within a new river channel: Interactions between fluvial processes, colonizing vegetation, and bank profile development", Environmental Management 38 (4): 580-596.

Güneralp, I.., Abad, J. D., Zolezzi, G. and Hooke, J. (2012). "Advances and challenges in meandering channels research", Geomorphology 163-164: 1-9.

Hammad, A. A., Lundekvam, H. and Borresen, T. (2004). "Adaptation of RUSLE in the eastern part of the Mediterranean Region", Environmental Management 34: 829-841.

Hasfurther, V. R. (1985). The Use Of Meander Parameters In Restoring Hydrologic Balance To Reclaimed Stream Beds. In The Restoration of Rivers and Streams Theories and Experience, Chapter 2, WWRC-85-44.

Hirano, A., Welch, R. and Lang, H. (2002). "Mapping from ASTER stereo image data: DEM validation and accuracy Assessment", ISPRS Journal of Photogrammetry \& Remote Sensing 57: 356-370.

Hoşgören, M. Y. (2007). Jeomorfoloji'nin Ana Çizgileri I. 6. Baskı, İstanbul: Çantay Kitabevi.

Hoşgören, M. Y. (2012). Hidrografya'nın Ana Çizgileri I. 7. Baskı, İstanbul: Çantay Kitabevi.

Howard, A. D. (1992). Modelling channel migration and floodplain sedimentation in meandering streams. In: Carling, P. A., Petts, G. E. (Eds.), Lowland Floodplain River, John Wiley, New York: Geomorphic Perspectives, pp.: 1-41.

İzbırak, R. (1978). Hidrografya Akarsular ve Göller. Ankara: Ankara Üniversitesi Dil ve Tarih-Coğrafya Fakültesi Yayınları, Erol Ofset Matbaacılık.

Kantürer, O. (1993). Gönen Havzasının Jeomorfolojisi. Yayınlanmamış Doktora Tezi, İstanbul: İstanbul Üniversitesi Sosyal Bilimler Enstitüsü.

Kazancı, N., Emre, Ö., Erkal, T., Görür, N., Ergin, M. ve İleri, Ö. (1997). "Güney Marmara Deltaları: Kocasu ve Gönen Çayı Deltalarının Morfolojisi ve Tortul Yapısı", Güney Marmara Bölgesinin Neojen ve Kuvaterner Evrimi. YDABÇAG 426/G, Ankara.

Kazancı, N., Emre, Ö., Erkal, T., Görür, N., Ergin, M. ve İleri, Ö. (1999). “Kocasu ve Gönen Çayı Deltalarının (Güney Marmara kıyıları) Güncel Morfolojileri ve Tortul Fasiyesleri", Maden Tetkik ve Arama Enstitüsü Dergisi 121: 33-50.

Khatsuria, R. M. (2008). "How and why rivers meander?", Hydrotopics. http://hydrotopics.wordpress.com/, Son erişim 01 Kasım 2013.

Koç, T. (2013). Türkiye'nin Morfometrik Özellikleri, Prof. Dr. İlhan Kayan'a Armağan, (Editör: Prof. Dr. Ertuğ ÖNER), Ege Üniversitesi Yayınları Edebiyat Fakültesi Yayın No: 181, s.: 433-467, İzmir.

Kondolf, G. M. (2006). "River restoration and meanders", Ecology and Society 11 (2): 42-57.

Leopold, L. B. and Wolman, M. G. (1957). "River channel patterns: braided, meandering and straight", U.S. Geological Survey Professional Paper 282-B: 39-85.

Leopold, L. B. and Wolman, M. G. (1960). "River Meanders", Geological Society of America Bulletin 71: 769-794.

Mueller, J. E. (1979). "Problems in the Definition and Measurement of Stream Length", Professional Geographer 31(3): 306-311. 
Nanson, G. C. and Beach, H. F. (1977). "Forest succession and sedimentation on ameandering-river floodplain, Northeast British Columbia, Canada", Journal of Biogeography 4 (3): 229-251.

Özdemir, H. (2007). Havran Çayı Havzasının (Balıkesir) CBS ve Uzaktan Algılama Yöntemleriyle Taşkın ve Heyelan Risk Analizi. Yayınlanmamış Doktora Tezi, İstanbul: İstanbul Üniversitesi Sosyal Bilimler Enstitüsü.

Özdemir, H. (2011). Havza Morfometrisi ve Taşkınlar. Fiziki Coğrafya Araştırmaları: Sistematik ve Bölgesel (Ed.: Deniz Ekinci), İstanbul: Türk Coğrafya Kurumu Yayınları No: 6, s.: 507-526.

Özdemir, M. A. ve Bahadır, M. (2008). “CBS ile Armutlu Yarımadasının Morfometrik Özellikleri", I. Ulusal Jeomorfoloji Sempozyumu, 20-23 Ekim 2008, Çanakkale, s.: 216-227.

Özşahin, E. (2008). “Gönen Ovasında Pirinç Tarımı”, Fırat Üniversitesi Sosyal Bilimler Dergisi, 18 (2): 49-70.

Özşahin, E. (2011). "Gönen Havzasında Jeomorfolojik Birimlerle Arazi Kullanımı Arasındaki iliş̧ki (Balıkesir)", Adıyaman Üniversitesi Sosyal Bilimler Enstitüsü Dergisi 4 (7): 9-25.

Parker, G. (1976). “On the cause and characteristic scales of meandering and braiding in rivers", Journal of Fluid Mechanics 76: 457-480.

Piegay, H., Darby, S. E., Mosselman, E. and Surian, N. (2005). "A review of techniques available for delimiting the erodible river corridor: a sustainable approach to managing bank erosion", River Research and Applications 21 (7): 773-789.

Riley, J. D. and Rhoads, B. L. (2012). "Flow structure and channel morphology at a natural confluent meander bend", Geomorphology 163-164: 84-98.

Salo, J., Kalliola, R., Hakkinen, I., Makinen, Y., Niemela, P., Puhakka, M. and Coley, P. (1986). "River dynamics and the diversity of Amazon lowland forest", Nature 322: 254-258.

Selim, H. H. and Tüysüz, O. (2013). "The Bursa-Gönen Depression, NW Turkey: a complex basin developed on the North Anatolian Fault", Geology Magazine 1-21.

Strahler, A. N. (1952). "Hypsometric (Area-Altitude) Analysis of Erosional Topography", Geological Society of America Bulletin 63: 1117-1142.

Strahler, A. N. (1954). "Quantitative Geomorphology of erosional landspaces", C.-R. 19 th International Geology Cong., Algiers, 1952, sec. 13, pt. 3, pp.: 341-354.

Strahler, A. N. (1973). "Akaçlama Havzalarının Jeomorfoloji Incelemelerinde Nicel Çözümler", Çeviren: Arpat, E. ve Güner, Y., Jeomorfoloji Dergisi, 5: 103-117.

Sun, T., Meakin, P., Jossang, T. and Schwarz, K. (1996). “A simulation model for meandering rivers", Water Resources Research 32 (9): 2937-2954.

Tari, U. ve Tüysüz, O., (2008), İzmit Körfezi ve Çevresinin Morfotektoniği, İstanbul Teknik Üniversitesi, iTÜ Dergisi/d Mühendislik, Cilt: 7, Sayı: 1, s.: 17-28.
The British Geographer (2013). http://thebritishgeographer.weebly.com/floods-and-river-management.html. Son erişim 01 Kasım 2013.

Verstappen, H. Th. (1983). Applied Geomorphology. Amsterdam: Elsevier Sci. Publ. Co.

Ward, J. V., Tockner, K., Arscott, D. B. and Claret, C. (2002). "Riverine landscape diversity", Freshwater Biology 47 (4): 517-539.

Watershed Protection Department (2013). <https://www.austintexas.gov/faq/geomorphic-analysis>. Son erişim 01 Kasım 2013.

Yıldırım, A. ve Karadağon, S. (2011). "Raman Dağları Güneyinde (Dicle Vadisi) Morfometrik ve Morfotektonik Analizler", Dicle Üniversitesi Ziya Gökalp Eğitim Fakültesi Dergisi 16: 154-166.

Zavoianu, I. (1985). Morphometry of Drainage Basins. Developments in Water Science, 20. AmsterdamOxford-New York-Tokyo: Elsevier. 